\title{
DIAMONDS IN CANADA
}

\author{
By B. A. Kjarsgaard and A. A. Levinson
}

\begin{abstract}
A newcomer (since 1998) as a supplier of rough diamonds to the world market, Canada is currently the seventh most important diamond producer by weight and fifth by value. This article chronicles the history of the exploration for, and discovery of, primary diamond deposits throughout Canada (538 kimberlites are currently reported), with particular emphasis on the important kimberlite pipes in the Northwest Territories. Typically, these pipes are small but have high diamond grades. Sales of the rough diamonds, and the fledgling cutting and polishing industry in Canada, are described, along with branding initiatives and the marketing strategies of the producers. Canada will become an increasingly significant supplier of rough diamonds as prolific new mines start production, and this will have a growing impact on the world diamond industry.
\end{abstract}

$\mathrm{F}$ or the first 60 years of the 20th century, the vast majority of diamonds came from kimberlite pipes and alluvial deposits in just a few countries in southern and western Africa, with minor contributions of alluvial diamonds from elsewhere, mainly South America (Janse, 1995a, 1996). This changed when diamonds were found in kimberlite or lamproite occurrences on other continents and elsewhere in Africa. The most important of these new discoveries resulted in major new production in Russia (then the Soviet Union) in the 1960s, Botswana in the 1970s, and Australia in the 1980s (Levinson et al., 1992). Since the 1990s, the spotlight has been on Canada, and Canadian diamonds promise to play an ever-greater role in the world market (figure 1).

This article provides a synopsis of the history of Canadian diamond exploration in the first 60 years of the $20^{\text {th }}$ century, followed by a comprehensive review of diamond exploration and discoveries in Canada since the 1960s. Special attention is given to the key events and discoveries in the 1990s, starting with the Lac de Gras area in the Northwest Territories (NWT), followed by Alberta, Saskatchewan, Ontario, and, finally, Quebec. Nothing has yet matched the excitement of the opening of Canada's first diamond mine, the Ekati Diamond $\mathrm{Mine}^{\mathrm{TM}}$, in 1998, but a number of other projects are either at the construction stage (the Diavik project) or in advanced stages of evaluation or development (Snap Lake, Gahcho Kué, Jericho, and Victor). We will also examine diamondiferous kimberlites, such as those in Saskatchewan and Alberta, that have significant potential. In total, approximately 538 kimberlites are now known throughout Canada (figure 2; predominantly in the NWT), over $50 \%$ of which contain diamonds. Ninety percent of these have been found in the last decade.

The unusual characteristics of the Lac de Gras kimberlites (such as their small size but high diamond grades) are compared with those of producing kimberlites worldwide. The current and anticipated contributions of rough diamonds from Canada's mines to the world supply are discussed, as are the manufacturing and marketing (including branding) of Canadian diamonds. Note that a glossary is provided on page 212; terms defined therein are shown in italics the first time they appear in the text.

This review is based on, and limited by, the information available from recognized sources, mainly the open literature, including public statements from

See end of article for About the Authors and Acknowledgments. GeMs \& Gemology, Vol. 38, No. 3, pp. 208-238.

(C) 2002 Gemological Institute of America 
Figure 1. The first Canadian diamonds to enter the world market

came from the Ekati Diamond Mine ${ }^{\mathrm{TM}}$, which opened in 1998 after decades of exploration by various companies and individuals. Each of the Ekati diamonds in the rings weighs approximately $1 \mathrm{ct}$, and the loose Ekati diamond weighs $1.29 \mathrm{ct}$; the diamonds in the earrings are each $0.10 \mathrm{ct}$. Courtesy of BHP Billiton Diamonds Inc.; photo $($ GIA and Harold e) Erica Van Pelt.

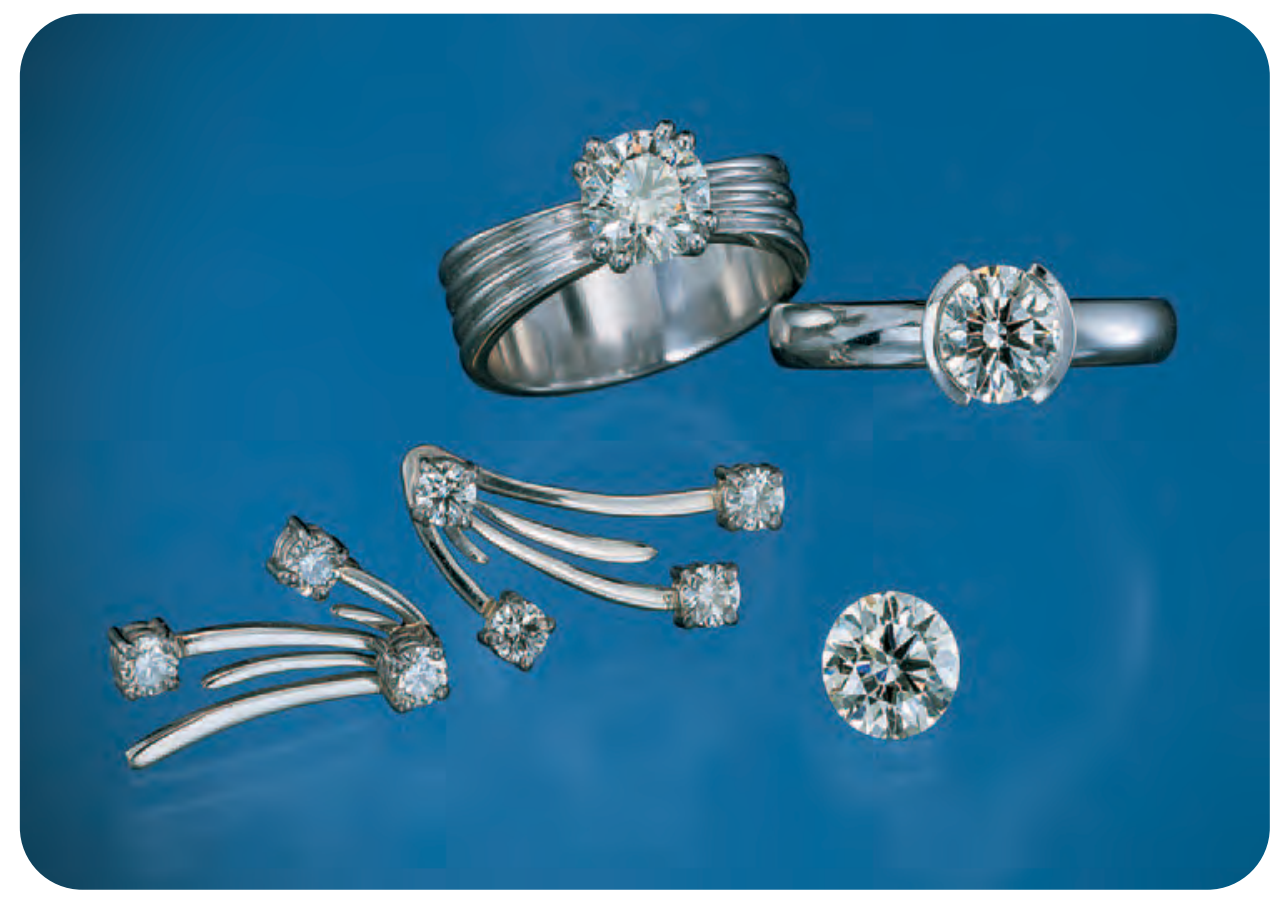

exploration groups. However, much information is unpublished, veiled in the secrecy of mining company files. For example, De Beers ${ }^{1}$ divulged in 1999 that since it started exploring in Canada in the early 1960s, it had discovered more than 170 kimberlites (some with joint-venture partners) in 11 different regions (Beardmore-Gray, 1999); no information has been made public on most of these kimberlites or the specific regions. While it is impossible to estimate what other information has not been revealed, we believe that we have omitted no major discoveries.

\section{BACKGROUND}

The possibility of diamonds occurring in Canada was raised over a century ago by Professor W. H. Hobbs (1899), who was the first person to make a convincing argument that diamonds in the Great Lakes states were transported by glaciers from a specific region in Canada (the James Bay Lowland; figure 3). Isolated discoveries of diamonds were reported in the eastern U.S. (e.g., North Carolina) as early as the 1840s, but diamonds found in the Great Lakes states from 1876 onward are the only ones of

\footnotetext{
${ }^{1}$ The Canadian exploration arm of De Beers Consolidated Mines Ltd. has operated, since 1960, under a variety of corporate names: Hard Metals Canada Ltd., Canadian Rock Co. Ltd., Diapros Canada Ltd., Monopros Ltd., and most recently De Beers Canada Exploration Inc. Similarly, Rio Tinto plc. and their wholly owned subsidiaries have explored for diamonds in Canada under different names, including Kennecott Canada Ltd., over the years.
}

significance from a Canadian perspective. Nevertheless, serious diamond exploration did not begin until the 1960s, and major kimberlite discoveries were not made until the 1980s. Why did it take so long to discover kimberlite pipes in Canada if they are actually relatively abundant? The answer is twofold: logistical and glacial.

Logistical factors include the remoteness and inaccessibility of some of the most favorable geologic areas (e.g., Archean cratonic rocks in the NWT, Nunavut, northern Ontario, and Quebec; again, see figure 2). Further, large portions of these areas consist of small, shallow lakes on which floatplanes cannot land as they routinely do in other parts of Canada. Finally, the climate limits the field season for regional exploration to only five months (May-September) or less. These factors have made exploration in much of Canada challenging and expensive. Diamond exploration was also hampered by the effects of glaciation (e.g., the deposition of glacial drift) until indicator mineral transport in glacial materials was understood. Essential aspects of glaciation, as they apply to diamond exploration in Canada, are presented in box A.

\section{0-1959: SIX DECADES OF CONTEMPLATION AND INACTIVITY}

In the 60 years following the publication of the Hobbs (1899) article, many additional diamond discoveries in glacial drift were reported in the Great Lakes states (e.g., Blatchley, 1903; Hausel, 1995), 


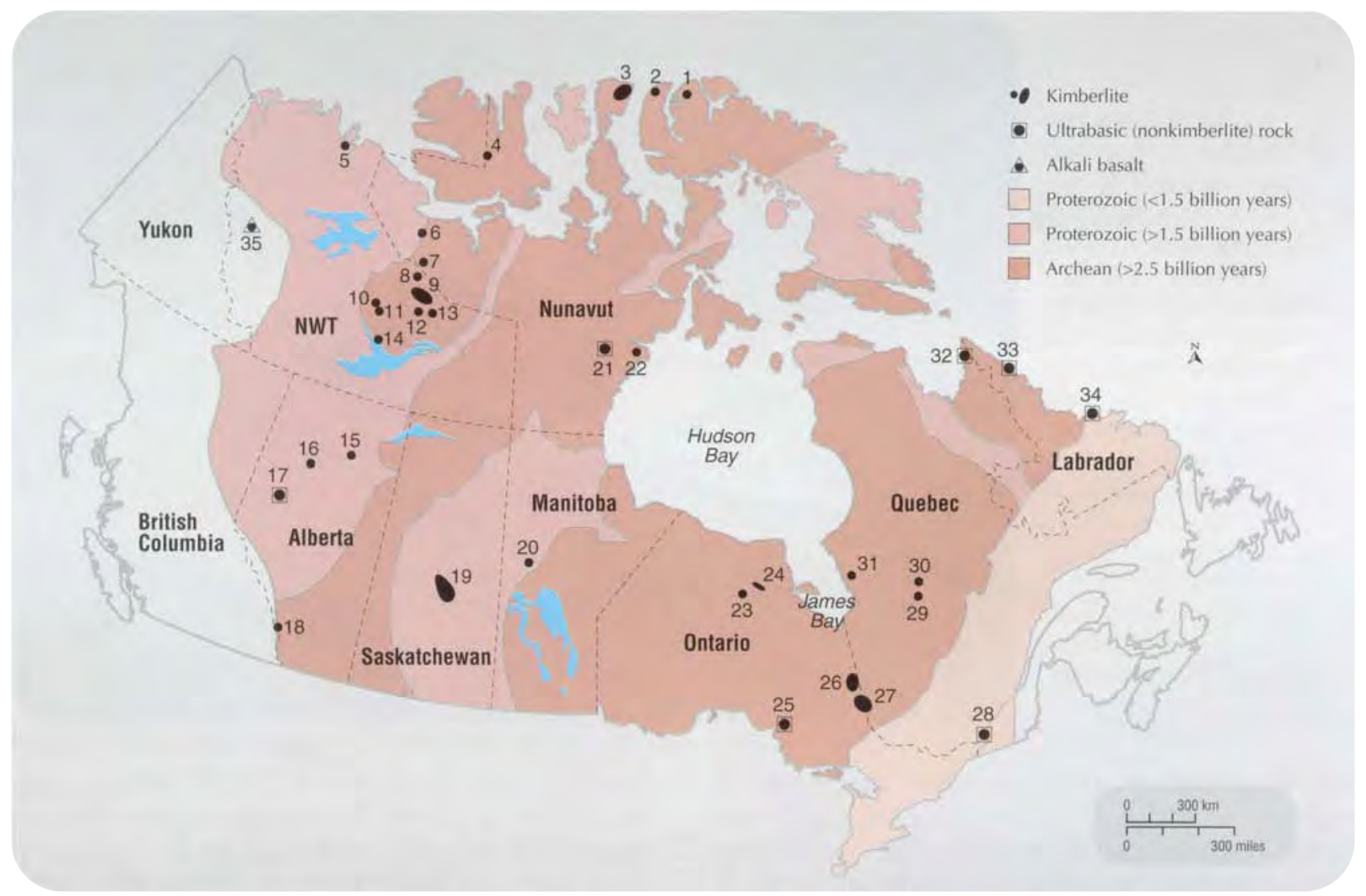

Figure 2. Canadian kimberlites, and other rocks that are sometimes associated with diamonds, are shown here with the major geological terranes. Diamonds have been confirmed at all the kimberlite localities except nos. 20 and 22. Various intermediate to ultrabasic (nonkimberlitic) rocks mentioned in the text are also shown; all except nos. 33 and 34 contain diamonds. Localities: (1) North Baffin Island; (2) Brodeur Peninsula; (3) Somerset Island; (4) Victoria Island; (5) Darnley Bay; (6) Kikerk Lake (Coronation Gulf); (7) Contwoyto Lake; (8) Ranch Lake; (9) Lac de Gras; (10) Snare Lakes; (11) Carp Lake; (12) Snap Lake; (13) Gahcho Kué (Kennady Lake); (14) Dry Bones Bay; (15) Birch Mountains; (16) Buffalo Hills; (17) Mountain Lake ultrabasic pipes; (18) Cross; (19) Fort à la Corne; (20) Snow Lake-Wekusko; (21) Akluilâk minette dike; (22) Rankin Inlet; (23) Kyle Lake; (24) Attawapiskat; (25) Wawa ultrabasic dikes and volcanic rocks; (26) Kirkland Lake; (27) Lake Timiskaming; (28) Ile Bizard alnöite; (29) "Indicator lake"; (30) Otish Mountains; (31) Wemindji; (32) Torngat Mountains aillikite dikes; (33) Saglek aillikite dikes; (34) Aillik Bay aillikite dikes; (35) Mountain diatreme alkali basalt. All these localities are mentioned in the text except for nos. 1, 2, 5, 20, and 22 (which are listed in table 3), and nos. 21, 33, and 34 (which are of minor importance and are not mentioned in the text or tables). Specific localities are cited in the text as, e.g., "figure 2 [26]," with the locality number in brackets.

mostly in Indiana and Illinois, for a total of 81 by 1967 (Gunn, 1968). During this time, however, little was written about diamonds or their primary sources in Canada. For this period (1900-1959), we found only 11 publications (excluding a few newspaper and other unsubstantiated reports) that bear directly on the subject: seven articles (Blue, 1900; Blatchley, 1903; Bell, 1906; Satterly, 1949; Field, 1949 and 1950, which are essentially identical and considered one source; Meen, 1950; and Douglas and MacGregor, 1952), two abstracts (Farrington, 1908; Kunz, 1931), and two minor entries of about 65 words each (Kunz, 1906, 1913). At the same time, diamond exploration activities in Canada also were limited (table 1).

Blue (1900) suggested that the diamonds might originate from carbonaceous slates in northern Ontario (e.g., in the Sudbury area). Blatchley (1903) and Kunz (1931) were favorably inclined toward two Canadian sources for the Great Lakes diamonds: the James Bay area and the north shore of Lake Superior (figure 3). Bell (1906) favored multiple sources in the Lake Superior-Lake Huron region, but rejected the James Bay Lowland because of the great distance from the diamond occurrences. Farrington (1908) proposed, without specifics, the general region of 


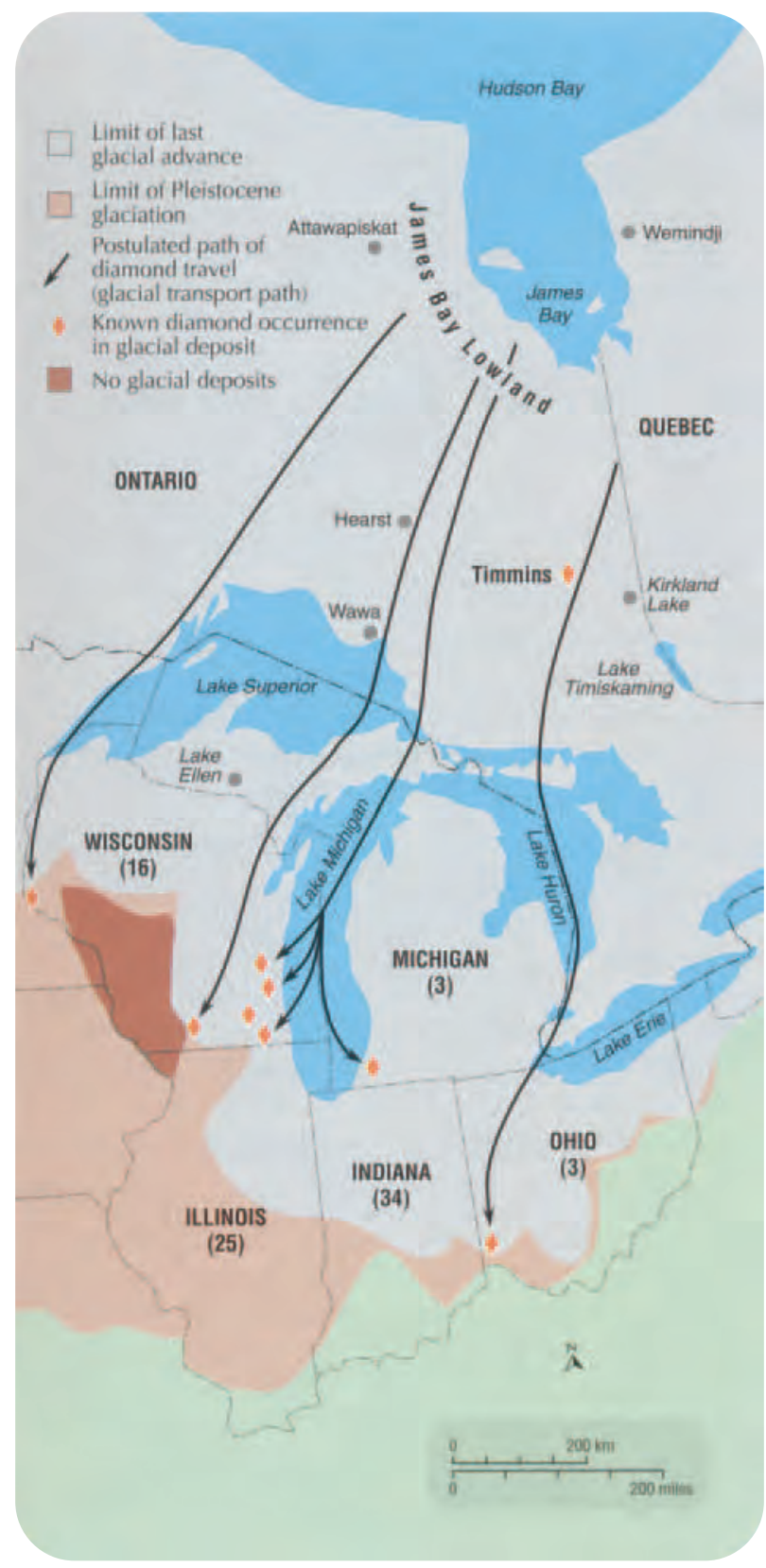

Figure 3. Early evidence of possible diamond-bearing kimberlites in Canada was provided by the discovery of isolated diamonds in glacial deposits in the Great Lakes states of the U.S. This map shows the limit of Pleistocene glaciation and the last glacial advance, the number of known diamond occurrences in each state (in parentheses), and the paths that the diamonds may have taken from their presumed source(s) in the James Bay Lowland. Also indicated is the location of the first authenticated diamond found (in 1971) in glacial deposits in eastern Canada (near Timmins): the $0.255 \mathrm{ct}$ Jarvi diamond. The kimberlites at Lake Ellen, Michigan, have been suggested, but never confirmed, as a possible source of the diamonds in the Great Lakes states. After Hobbs (1899), Brummer (1978, 1984), and Levinson et al. (1992).
Lake Superior as the only source. Although Satterly (1949) never mentioned the word diamond, he included the first reported occurrence of kimberlite in Canada: two thin dikes (the largest 6 inches [15 $\mathrm{cm}$ ] wide) that were intersected during drilling for gold in Michaud Township, near Kirkland Lake, Ontario, in 1946 (figure 2 [26]).

Field $(1949,1950)$ reviewed publications of the previous half-century and was enthusiastic about the possibility of diamonds occurring in Canada but offered no new insights. Meen (1950) observed that all the major diamond-bearing kimberlites known at that time (i.e., those in South Africa) were associated with rocks of Precambrian age. As much of Canada is underlain by rocks of similar ancient age, he recommended exploration for diamonds in those areas. Nevertheless, in the 1950s most Canadian mining companies and academics believed that economic diamond deposits could be found only in southern Africa (e.g., Duval et al., 1996).

There are brief reports of diamonds being sought, unsuccessfully, by survey parties during construction of the Transcontinental Railroad, immediately north of the Great Lakes (Kunz, 1906), in northern Quebec near Matagami Lake (Kunz, 1913), and in what turned out to be a meteorite crater in the Ungava region of northern Quebec (Meen, 1950). Also during these first $60+$ years, diamonds were periodically reported from various parts of Canada. However, all were misidentifications, unsubstantiated because of poor documentation, or of doubtful authenticity (including probable fraud). These reported discoveries are not considered further in this article, but are listed in the Gems \&) Gemology Data Depository (http://www.gia.edu/gandg/ ggDataDepository.cfm).

Douglas and MacGregor (1952) recounted, in detail, an unsuccessful attempt in 1910 by five prospectors to find diamonds in the Nottaway River area, Quebec, near James Bay. To the best of our knowledge, this is the only recorded, apparently creditable, attempt before 1960 at field exploration specifically for diamonds.

By the mid-1950s, however, the foundation was being laid for systematic diamond exploration programs in the succeeding decades as a few academics-as well as geologists and engineers employed by mining companies-expressed interest in Canada's diamond potential. Notably, in 1956 P. V. Freeman (then a Ph.D. candidate at McGill University) suggested that sampling eskers [see box A] would yield results similar to those 


\section{GLOSSARY}

aeromagnetic survey An airborne geophysical survey using a towed sensor that can detect magnetic anomalies; these anomalies may indicate the presence of kimberlite.

Archean The earlier (i.e., prior to 2.5 billion years ago) of two great divisions of Precambrian time; the earliest eon of geologic time.

cratons Large, ancient, stable portions of the earth's crust (continental nuclei) in which all commercial diamond-bearing kimberlites have been found.

diatreme A pipe (conduit) filled with angular volcanic fragments that was formed by a gaseous explosion. Many of the diamond-bearing kimberlites at the type locality in Kimberley, South Africa, are diatremes.

dike A tabular igneous intrusion that cuts across the structure or bedding of pre-existing rock. On rare occasions (as at Snap Lake, NWT), economic kimberlites will occur as dikes.

esker A long, narrow, sinuous ridge composed of glacial drift (typically sand and gravel) deposited by subglacial streams.

exploration grade The grade (ct/tonne) of a deposit estimated from a relatively small bulk sample and subject to revision with additional sampling before mining is initiated.

exploration stone value The value of rough diamonds (US\$/ct) from a deposit estimated from $<5,000$ carats of diamonds and subject to revision with additional sampling before mining is initiated.

glacial drift A general term for all material transported and deposited by or from a glacier or by running water emanating from a glacier.

glacial till Unsorted rock materials (e.g., clay, sand, gravel) transported and deposited by a glacier, without reworking by meltwater. indicator minerals Minerals geologically associated with diamonds (e.g., Cr-rich pyrope garnet, Crspinel), but significantly more abundant, which can be used as proxies to locate a primary source of diamonds.

mafic An igneous rock composed chiefly of one or more iron- and magnesium-based minerals; such rocks are generally dark colored. On rare occasions (as at Wawa, Ontario), mafic rocks will contain diamonds but so far they have not been economic.

microdiamond A rough diamond that is $<0.5 \mathrm{~mm}$ (in some definitions $<1.0 \mathrm{~mm}$ ) in diameter; usage of this term varies, and in some cases the diameter applies to only one dimension whereas in others it applies to all dimensions.

modeled grade The grade (ct/tonne) of a deposit estimated from a relatively small sample based on statistical methods using micro- and macro-diamond size counts (see, e.g., Rombouts, 1999).

modeled stone value The value of rough diamonds (US\$/ct) from a deposit estimated from a relatively small sample, based on statistical methods using values from micro- and macro-diamond counts (see, e.g., Rombouts, 1999).

pipe Cylindrical or carrot-shaped structure that is filled with any one of several types of kimberlite (e.g., hypabyssal, diatreme, resedimented).

ramp-up The time and/or process required to bring mine production to full capacity.

sill A tabular igneous intrusion that parallels the bedding or foliation of the host rock.

ultrabasic An igneous rock, such as kimberlite or lamproite, having a very low silica $\left(<45 \% \mathrm{SiO}_{2}\right)$ content. obtained from stream sediments, which are very effective for mineral exploration in nonglaciated areas (Brummer et al., 1992a). A few years later, in 1960, De Beers signaled its interest in Canada when it rehired Canadian geologist Dr. Mousseau Tremblay, who had left the company only the year before to return to Canada (Duval et al., 1996). Dr. Tremblay had several years of diamond exploration experience in East Africa, including the area around the Williamson (Mwadui) mine in Tanganyika (now Tanzania).

\section{0-1969: SERIOUS DIAMOND EXPLORATION BEGINS}

This decade ushered in the modern era of diamond exploration in Canada, with the sudden appearance of several diamond exploration programs by two 
companies in particular: Selco Exploration Co. (the Canadian subsidiary of Selection Trust, a British company) and De Beers (South Africa). Both companies were experienced diamond explorers internationally, but were new to North America. In addition, studies related to diamond exploration were undertaken by various federal and provincial geological surveys. These early projects attempted to evaluate large areas, with spotty results, as described below.

Northeastern Ontario: James Bay Lowland. Initial efforts to find diamonds in Canada were concentrated in the James Bay Lowland of northern Ontario, an area that is extremely difficult to explore because of the abundant bogs, uninterrupted glacial cover, and poor drainage (figure 4). Selco and De Beers found kimberlite indicator minerals (including pyrope garnet) at 20 locations over a large area $\left(\sim 10,000 \mathrm{~km}^{2}\right)$, but no kimberlite or diamonds (Brummer, 1978). Work by the Ontario Department of Mines in 1966 (Brown et al., 1967) also confirmed the presence of indicator minerals (Kong et al., 1999). The activities of all three groups supported the suggestion of Hobbs (1899) that the James Bay Lowland might be the source of the Great Lakes diamonds.

Northeastern Ontario: Kirkland Lake-Lake Timiskaming. In the early 1960s, De Beers followed a trail of indicator minerals in an esker (and glacial till) to the Guigues pipe (Lake Timiskaming area; figure 2 [27]) in Quebec. This was the first kimberlite pipe found as a result of geologic exploration rather than by accident. However, the absence of diamonds in a multi-tonne sample of glacial material immediately "down-ice" of the kimberlite precluded drilling or sampling the kimberlite itself ( $M$. Tremblay, pers. comm., 1998). Early exploration in the Kirkland Lake-Lake Timiskaming area of Ontario (and adjacent parts of Quebec) was at least in part due to the 1946 discovery of thin kimberlite dikes in a gold mine near Kirkland Lake (Satterly, 1949). In addition, government-funded studies in this area in the early to mid-1960s demonstrated the validity of esker sampling for kimberlite indicator minerals (Lee, 1965; Lee and Lawrence, 1968).

Ile Bizard, Quebec. Attention soon shifted to Ile Bizard, an island in the St. Lawrence River, $14 \mathrm{~km}$ west of Montreal (figure 2 [28]). Several intrusions there were first described by Harvie (1910) as alnöites (a rare rock macroscopically similar to kimberlite, but not known to contain economic diamond deposits).
TABLE 1. Milestones in the history of diamond discoveries in Canada.

\begin{tabular}{|c|c|c|}
\hline Year & Milestone & Reference \\
\hline 1899 & $\begin{array}{l}\text { First documented suggestion that diamonds } \\
\text { occur in Canada }\end{array}$ & Hobbs (1899) \\
\hline 1946 & $\begin{array}{l}\text { First Canadian kimberlites (two thin dikes) } \\
\text { found near Kirkland Lake, Ontario }\end{array}$ & Satterly (1949) \\
\hline 1956 & $\begin{array}{l}\text { The use of eskers as a sampling medium in } \\
\text { glacial terrain first suggested by P. V. Freeman }\end{array}$ & $\begin{array}{l}\text { Brummer et al. } \\
\text { (1992a) }\end{array}$ \\
\hline 1957 & $\begin{array}{l}\text { Information on using indicator minerals for } \\
\text { regional diamond exploration (pioneered in } \\
\text { Russia) first available in English }\end{array}$ & Davidson (1957) \\
\hline 1960 & $\begin{array}{l}\text { De Beers signals interest in diamond exploration } \\
\text { in Canada with the recruitment of geologist } \\
\text { Dr. Mousseau Tremblay }\end{array}$ & Duval et al. (1996) \\
\hline 1960 & $\begin{array}{l}\text { First modern diamond exploration project in } \\
\text { Canada (by Selco) begins in the James Bay } \\
\text { Lowland }\end{array}$ & Brummer (1978) \\
\hline 1961 & $\begin{array}{l}\text { First regional heavy mineral survey across } \\
\text { Canada initiated by De Beers }\end{array}$ & Brummer (1978) \\
\hline $\begin{array}{l}\text { Early } \\
1960 \text { s }\end{array}$ & $\begin{array}{l}\text { First kimberlite pipe (Guigues in Quebec) } \\
\text { discovered by geological exploration, rather } \\
\text { than by accident, in the Lake Timiskaming } \\
\text { area }\end{array}$ & $\begin{array}{l}\text { M. Tremblay (pers. } \\
\text { comm., 1998) }\end{array}$ \\
\hline 1964 & $\begin{array}{l}\text { The Munro esker (Kirkland Lake, Ontario) study } \\
\text { is the first to publicly demonstrate the value of } \\
\text { eskers in diamond exploration in Canada }\end{array}$ & $\begin{array}{l}\text { Lee (1965); Lee } \\
\text { and Lawrence (1968) }\end{array}$ \\
\hline 1968 & $\begin{array}{l}\text { First diamonds ( } 10 \text { minute) recovered from a } \\
\text { primary source in Canada, at Ile Bizard, Quebec }\end{array}$ & $\begin{array}{l}\text { Brummer (1978, } \\
\text { 1984) }\end{array}$ \\
\hline 1971 & $\begin{array}{l}\text { The Jarvi diamond ( } 0.255 \mathrm{ct} \text {, found near } \\
\text { Timmins, Ontario) is the first authenticated dia- } \\
\text { mond to be discovered in glacial drift in Canada }\end{array}$ & $\begin{array}{l}\text { Brummer (1978, } \\
\text { 1984) }\end{array}$ \\
\hline 1973 & $\begin{array}{l}\text { The first kimberlite field in Canada, the } \\
\text { Somerset Island field, is recognized }\end{array}$ & $\begin{array}{l}\text { Mitchell and Fritz } \\
\text { (1973) }\end{array}$ \\
\hline 1976 & $\begin{array}{l}\text { Exploration begins in the Cordillera; the Cross } \\
\text { diatreme in British Columbia is recognized as } \\
\text { kimberlite }\end{array}$ & Pell (1987) \\
\hline 1979 & $\begin{array}{l}\text { Otish Mountains ("Indicator lake") kimberlite } \\
\text { discovered in Quebec }\end{array}$ & Gehrisch et al. (1979) \\
\hline $\begin{array}{l}1981- \\
1982\end{array}$ & $\begin{array}{l}\text { Charles E. Fipke and Stewart L. Blusson explore } \\
\text { the Mountain diatreme and Blackwater Lake } \\
\text { areas of NWT }\end{array}$ & $\begin{array}{l}\text { Fipke et al. (1995b); } \\
\text { Krajick (2001) }\end{array}$ \\
\hline $\begin{array}{l}1981- \\
1984\end{array}$ & $\begin{array}{l}\text { Numerous kimberlites discovered by De Beers } \\
\text { in the Kirkland Lake area (Ontario), establishing } \\
\text { the Kirkland Lake kimberlite field }\end{array}$ & Sage (1996) \\
\hline 1983 & $\begin{array}{l}\text { Fipke incorporates Dia Met Minerals to explore } \\
\text { for diamonds }\end{array}$ & See text \\
\hline 1987 & $\begin{array}{l}\text { First kimberlite found in Saskatchewan, at } \\
\text { Sturgeon Lake; discovery of the Fort à la Corne } \\
\text { kimberlite field announced in } 1989\end{array}$ & $\begin{array}{l}\text { Lehnert-Thiel et al. } \\
\text { (1992) }\end{array}$ \\
\hline 1988 & $\begin{array}{l}\text { The Attawapiskat kimberlite field (James Bay } \\
\text { Lowland, Ontario) discovered by De Beers }\end{array}$ & Kong et al. (1999) \\
\hline 1989 & $\begin{array}{l}\text { Fipke and Blusson arrive in Lac de Gras (NWT) } \\
\text { and begin to stake claims }\end{array}$ & $\begin{array}{l}\text { Fipke et al. (1995b); } \\
\text { Krajick (2001); see } \\
\text { text }\end{array}$ \\
\hline 1991 & $\begin{array}{l}\text { Diamond-bearing kimberlite discovered at } \\
\text { "Point lake" in the Lac de Gras area }\end{array}$ & See text \\
\hline 1997 & $\begin{array}{l}\text { First kimberlite discovered in Alberta, in the } \\
\text { Buffalo Hills }\end{array}$ & $\begin{array}{l}\text { J. A. Carlson et al. } \\
(1999)\end{array}$ \\
\hline 1998 & $\begin{array}{l}\text { The Ekati Diamond Mine in NWT officially } \\
\text { opens with mining of the Panda kimberlite }\end{array}$ & See text \\
\hline 1999 & $\begin{array}{l}\text { Government approval received to start con- } \\
\text { struction of the Diavik mine; diamond produc- } \\
\text { tion scheduled to begin in early } 2003\end{array}$ & See text \\
\hline
\end{tabular}




\section{Box A. Glaciation and Diamond Indicator MineralS}

Glaciation. During the Pleistocene epoch (1.6 million to 10,000 years ago), the time of the Ice Age, glaciers periodically covered up to $95 \%$ of Canada. As the glaciers advanced, they eroded the earth's surface, often transporting and scattering the abraded material (including the occasional diamond) many hundreds of kilometers from its source. Eventually, this material was deposited as glacial drift. Glacial drift in Canada may reach more than $300 \mathrm{~m}(\sim 1,000$ feet $)$ in thickness over buried valleys, but usually it is much shallower and in some places it is absent.

Kimberlite is generally softer than granite and other igneous and metamorphic rocks that are typical of the Precambrian Shield areas into which it is emplaced. Therefore it may be preferentially eroded,

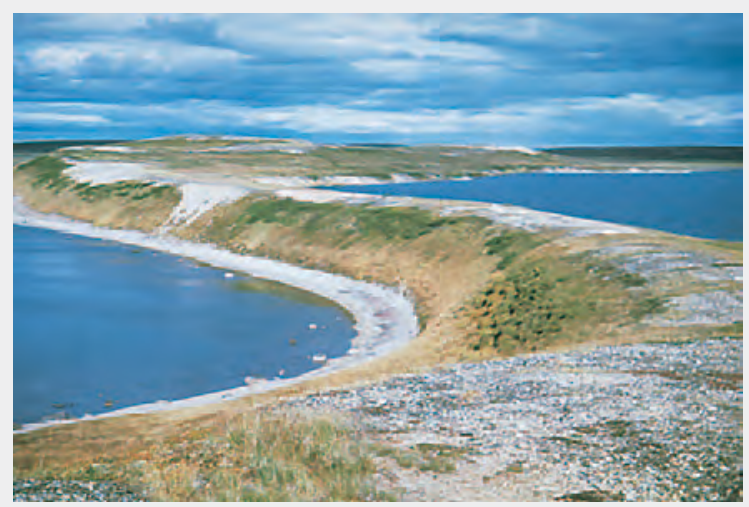

Figure A-1. The sinuous ridge shown here is an esker at Exeter Lake, NWT, located about $20 \mathrm{~km}$ northwest of the Ekati mine. This photo (looking east) was taken in 1955 in conjunction with a geological investigation of its heavy mineral content (Folinsbee, 1955), near the location that was sampled three decades later by C. E. Fipke. This esker can be traced for $\sim 515 \mathrm{~km}$ ( 320 miles); at this location, it is up to $24 \mathrm{~m}$ ( 80 feet) above lake level and $150 \mathrm{~m}$ wide in places. Photo courtesy of the Geological Survey of Canada; supplied by R. E. Folinsbee. sometimes deeply, by glaciers. Today, the resulting depressions are often occupied by lakes and swamps. This explains why numerous kimberlites are under lakes in certain parts of Canada, a possibility first mentioned by Meen (1950) and confirmed by the major kimberlite discoveries in the Lac de Gras area starting in 1991. Since kimberlites are not typically seen on the surface in Canada, diamond prospecting is based on the premise that indicator minerals and kimberlite boulders in glacial drift can be traced back to their primary source (see, e.g., McClenaghan et al., 2001).

Eskers are particularly important for prospecting in a glaciated area. These long (up to $500 \mathrm{~km}$ if gaps are included), narrow, sinuous ridges are composed of glacial drift that was deposited from subglacial streams (figure A-1). Geologists have traced diamond indicator minerals for great distances in eskers to locate numerous kimberlites (initially in Ontario, but later in the NWT).

Diamond Indicator Minerals. Diamonds are extremely rare, even in economic deposits (usually $<1$ ct/tonne of kimberlite). However, certain other minerals geologically associated with diamonds (e.g., Crrich pyrope garnet, Cr-spinel) are usually far more abundant (figure A-2). These diamond indicator minerals can therefore be used to locate the primary source of diamonds (figure A-3). The concept was initially used in the 1870s in South Africa on a local scale when the association of pyrope with diamond was first recognized (see Janse, 1996, for a summary of this topic). The great diamond discoveries in Yakutia (Russia) in the 1950s were achieved by large-scale sampling of stream sediments for indicator minerals (mainly pyrope; Davidson, 1957; Smith, 1960). In 1956, P. V. Freeman was the first on record to suggest that eskers could be used for sampling in diamond exploration. In Canada, glacial till, eskers, and stream sediments are sampled for indicator minerals.
De Beers acquired an option on the property in 1967. In 1968, the Pain de Sucre ("Sugar Loaf") occurrence yielded 10 minute diamonds weighing a total of 0.0605 ct (the largest, 0.0244 ct [2.44 points]), from a 29 cubic yard $\left[22 \mathrm{~m}^{3}\right]$ sample, which showed that the intrusions had no commercial potential. Nevertheless, these are the first authenticated diamonds recovered from a primary source of any type in Canada (for details of these occurrences, see Brummer, 1978, 1984; Raeside and Helmstaedt, 1982; and Mitchell, 1983).
Central and Western Canada. Starting in 1961, De Beers undertook systematic indicator mineral sampling of glacial materials and stream sediments from the foothills of the Rocky Mountains (in Alberta) east to the Appalachian region (in Quebec) and from the U.S. border north to $54^{\circ}$ latitude (Brummer, 1978; M. Tremblay, pers. comm., 1998). Lehnert-Thiel et al. (1992) indicate that De Beers found diamond indicator minerals in southeast Saskatchewan in 1963. There is no further published information on the results of this project. 
Many of the indicator minerals occur in various rock types in addition to kimberlite, so the recognition of those associated with diamonds requires training and experience. Initially, they were recognized by the characteristic colors (e.g., deep red or purplish red for pyrope, and "emerald" green for chrome diopside) of the grains. Later, in the 1950s and '60s, careful measurements of physical (e.g., R.I. and S.G.) or crystallographic (unit cell dimensions) properties became diagnostic. Starting in the early 1970s, the electron microprobe became the instrument of choice for analyzing the chemical composition of the small grains (see, e.g., Gurney and Switzer, 1973).

Today, there are classification schemes for all the important indicator minerals, based on their chemistry, that are capable of empirically predicting whether or not a specific grain could have originated from a diamondiferous kimberlite. The methods of

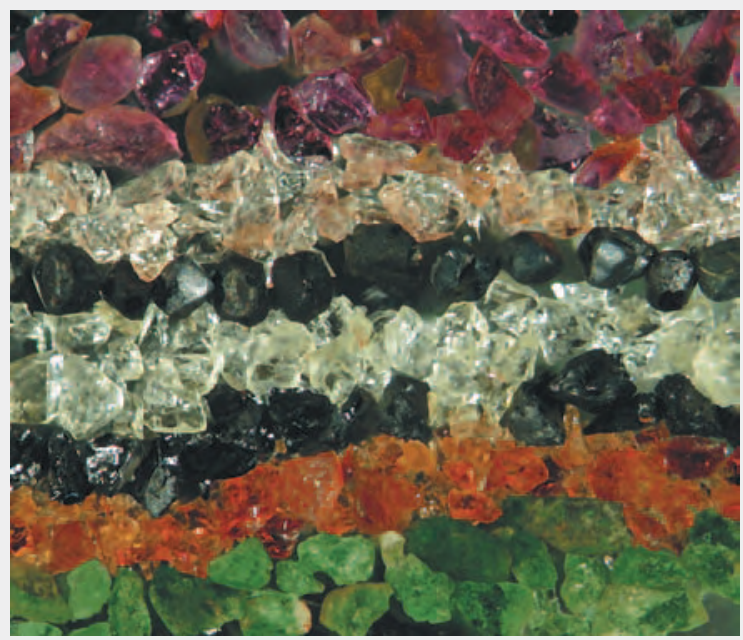

Figure A-2. Several indicator minerals are used to explore for kimberlites in Canada. These include, from top to bottom: Cr-pyrope garnet, eclogitic garnet, Cr-spinel, olivine, picroilmenite, Ti-pyrope garnet, and Cr-diopside. Photo by Penny R. Maki-Scott, Saskatchewan Research Council. diamond indicator mineral sample collection, analysis, and interpretation have become widely disseminated (see, e.g., Fipke et al., 1995a; McClenaghan and Kjarsgaard, 2001), although the finer points of interpretation are proprietary.

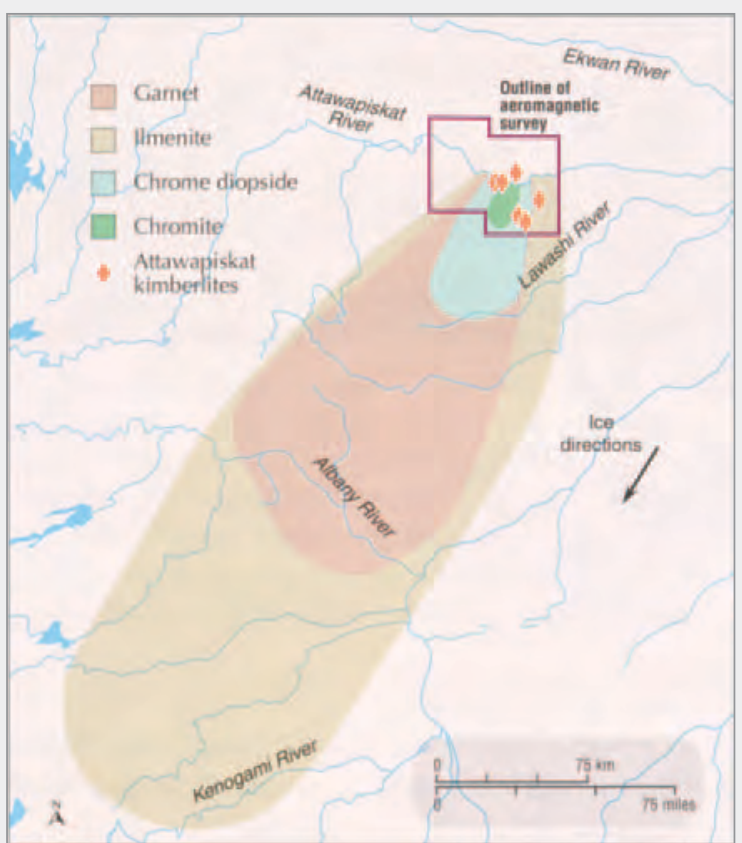

Figure A-3. In 1984-87, De Beers used indicator mineral sampling (assisted by airborne geophysical surveys) in the James Bay Lowland of northern Ontario to locate diamondiferous kimberlites in the Attawapiskat River area. The indicator-mineral dispersion patterns for chromite, chrome diopside, pyrope garnet, and ilmenite are shown here. Dispersion of the ilmenite grains is detectable more than $300 \mathrm{~km}$ from the kimberlite source, whereas chromite and chrome diopside yield much smaller dispersion halos closer to the source because they are more easily weathered. The indicator minerals were collected from streams that were eroding glacial deposits (after Kong et al., 1999).

\section{0-1979: FEW AND}

\section{DISAPPOINTING DISCOVERIES}

As the 1970s unfolded, exploration activity began to shift away from Ontario, mainly to the north and west. At the same time, interest from academics increased with, for example, the detailed study of kimberlites on Somerset Island in the Arctic archipelago (e.g., Mitchell and Fritz, 1973). Nevertheless, activities during this decade would eventually lead to the discovery and operation of
Canada's first diamond mine, in the Northwest Territories.

The Jarvi Diamond (Eastern Ontario). In late 1971, a 0.255 ct diamond was found by Reno Jarvi while sampling an esker near Timmins, Ontario (Brummer, 1978, 1984; again, see figure 3). Its primary source has never been located, but this was the first authenticated diamond to be found in glacial drift in Canadaalmost a century after the 1876 discovery of the first 
however, the Mountain diatreme alkali basalt was a significant factor in the sequence of events that led to the discovery of the Lac de Gras kimberlite field.

\section{0-1989: PERSEVERANCE BEGINS TO PAY OFF}

The 1980s opened with the most prominent exploration in Ontario, and with clear signs that diamond exploration was spreading throughout the country. Furthermore, mining companies recognized that a major problem had hindered their Canadian activities to date: Diamond experts with experience from other countries (e.g., in southern Africa, Australia) did not necessarily have a strong background in glacial geology. As a result, some had undertaken sampling programs in Canada without knowing the nature of the glacial materials being sampled (e.g., eskers, till). This resulted in a limited understanding of how far the glacial materials had been transported. In the 1980s, improved airborne geophysical surveys and the geological knowledge of glacial deposits, combined with sampling for diamond indicator minerals, led to many significant discoveries (again, see table 1).

Northeastern Ontario: James Bay Lowland. From 1979 to 1982, Selco, joined by Esso Minerals Canada in 1982, explored part of the James Bay Lowland north of Hearst, Ontario. They used airborne magnetic reconnaissance surveying to delineate potential kimberlite bodies, followed by more detailed ground geophysical surveying (Janse et al., 1989; Reed and Sinclair, 1991). Although the 45 alnöite bodies identified were of no economic interest, this represents the first large-scale geophysical survey in Canada to find a field of "kimberlite-like" pipes.

In 1984, De Beers started an annual regional survey program north of the area explored by Selco and Esso in the James Bay Lowland. The combination of stream sediment sampling for indicator minerals (see box A, figure A-3) and airborne magnetic surveys led them to the Attawapiskat River area (Kong et al., 1999; figure 2 [24]). Drilling in 1988 and 1989 confirmed 16 kimberlites, ranging from $0.4-15$ ha (1-37 acres), 15 of which contained diamonds.

Northeastern Ontario: Kirkland Lake. In the Lake Timiskaming area, De Beers drill tested the Guigues pipe (previously identified in the 1960s but not drilled) in 1981 and the Bucke pipe in 1983. Also in 1983, De Beers drill tested the A-4, AM-47,

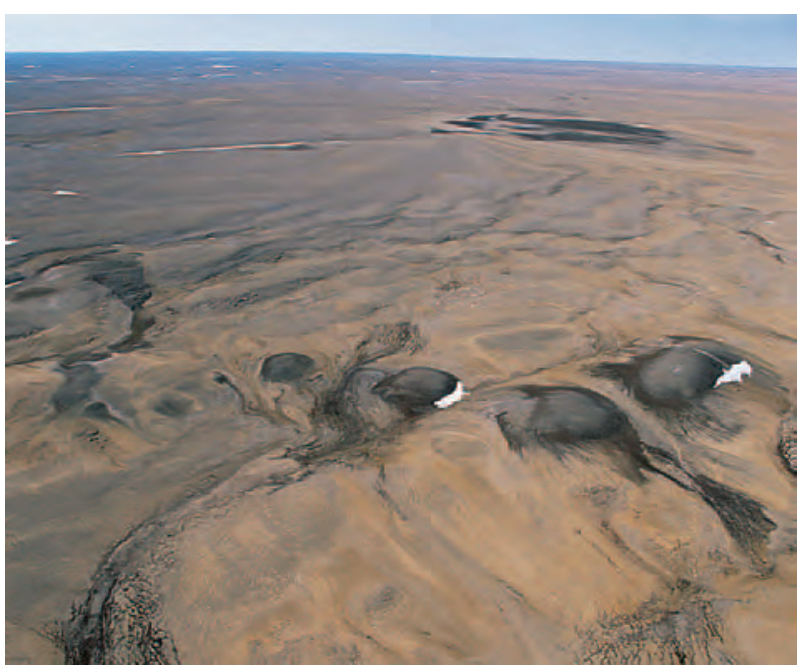

Figure 5. The Batty kimberlite is part of the Somerset Island kimberlite field (figure 2 [3]), the first kimberlite field discovered in Canada. In the foreground are five smaller satellite pipes, with the main Batty pipe in the background. The dark kimberlites stand out in contrast to the light-colored carbonate host rocks where they are exposed at the surface of this nonglaciated area. Photo taken in July 1990 by B. A. Kjarsgaard.

and B-30 kimberlite pipes in the Kirkland Lake kimberlite field. In 1984, De Beers drilled the Morrisette Creek kimberlite, bringing to six the number of kimberlite pipes it had discovered in the Kirkland Lake/Lake Timiskaming area. For the first time, a major kimberlite field was discovered by design by a

Figure 6. The Mountain diatreme (dark color; $>850 \mathrm{~m}$ across) is an alkali basalt in which some microdiamonds were reported. Located in the Mackenzie Mountains of the Northwest Territories, this diatreme was the starting point for the exploration path that eventually led to the discovery of the Lac de Gras kimberlite field. Photo taken in June 1979, looking south, by A. E. Oldershaw.

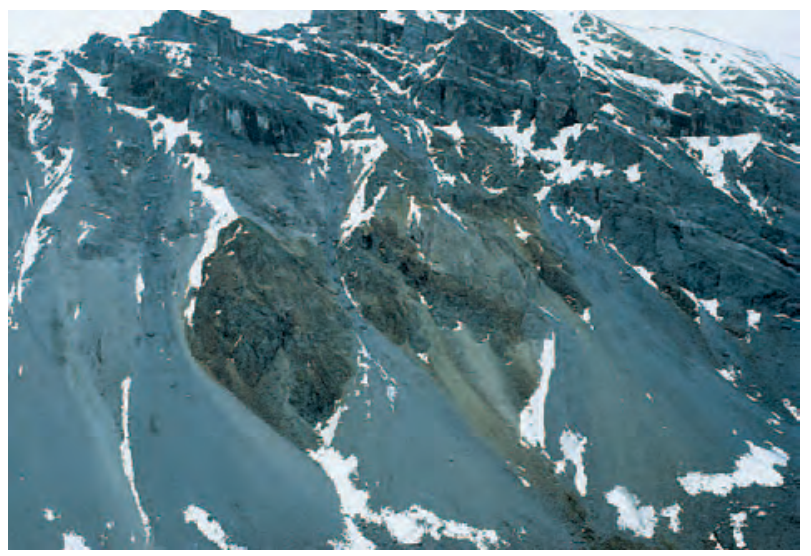



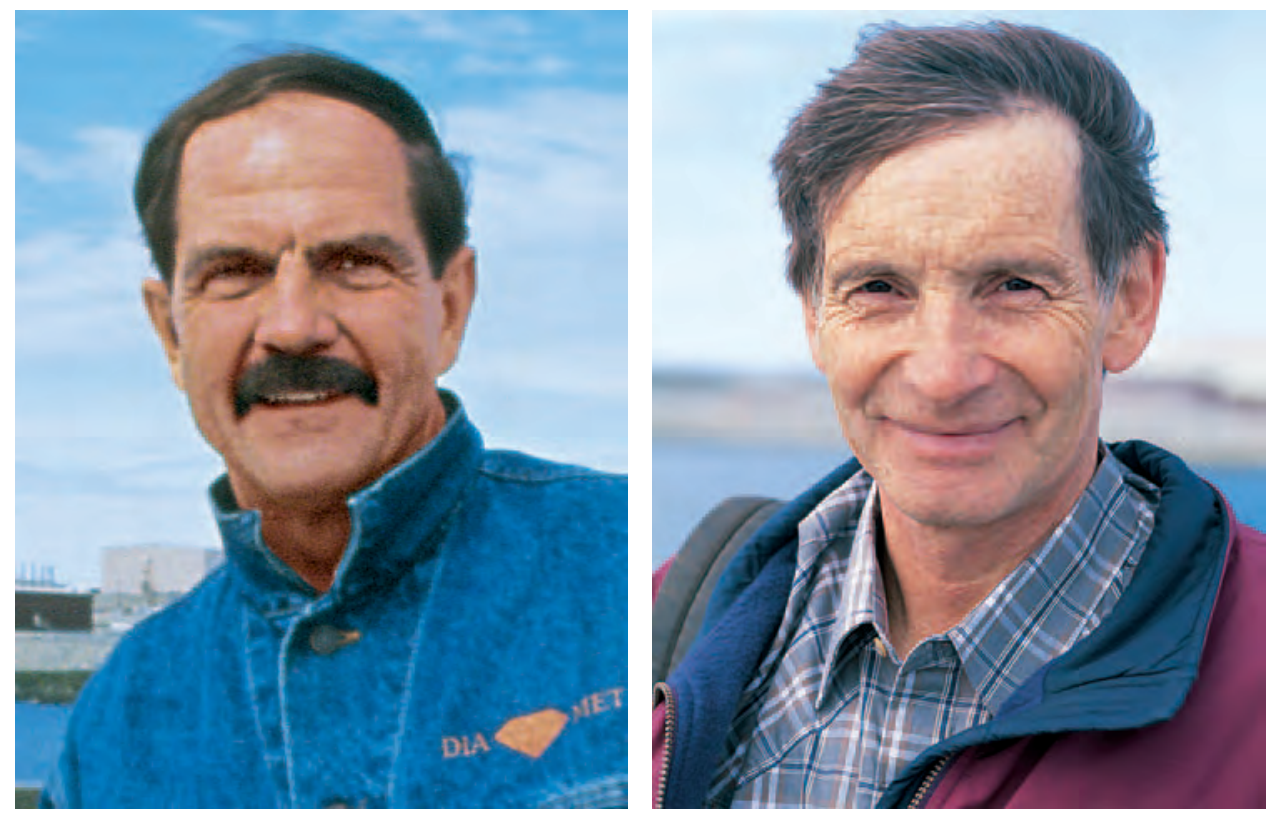

Figure 7. Geologists Charles E. Fipke (left) and Dr. Stewart L. Blusson (right) are credited with discovering the first kimberlite in the Lac de Gras field, NWT. Photos courtesy of BHP Billiton Diamonds Inc.

diamond exploration company. Additional kimberlites were found in this area by Falconbridge in 1984 and 1987, Homestake in 1987, and Lac Minerals in 1987 (Sage, 1996). However, the diamonds recovered were small (the largest $0.17 \mathrm{ct}$ ), and the best grade reported for any kimberlite was $0.02 \mathrm{ct}$ per tonne (Brummer et al., 1992b).

Saskatchewan. Diamond exploration in Saskatchewan started in 1987, when De Beers discovered diamondiferous kimberlite at Sturgeon Lake, about 40 km northwest of Prince Albert (Gent 1992a,b). Subsequent drilling, however, revealed that the kimberlite was a large glacially transported block $(200 \times 125 \times 40 \mathrm{~m})$. The few diamonds it contained were not economically significant (grade $<0.01$ ct/tonne; Scott Smith et al., 1996).

The De Beers activity prompted numerous companies to stake and evaluate claims in other parts of Saskatchewan (Lehnert-Theil et al., 1992). Most notable were joint-venture partners Uranerz Exploration and Mining Ltd. and Cameco Corp., both primarily uranium-mining companies. In 1988, they staked ground in the Fort à la Corne area, about 50 $\mathrm{km}$ east of Prince Albert (figure 2 [19]), based principally on regional geophysical maps published by the Geological Survey of Canada from 1967 to 1969 (Lehnert-Theil et al., 1992; Gent, 1992b). In late 1989, Uranerz and Cameco announced the discovery of seven kimberlite pipes, the first of many announcements over the next few years that would reveal that the Fort à la Corne kimberlite field is one of the largest in the world. Strnad (1991) noted that this find, based on the use of published government aeromagnetic maps, represented the least expensive, fastest, and most productive approach ever applied to the discovery of a major kimberlite field.

Cordillera Region (and Eastward to Lac de Gras, NWT). When Superior Oil and Falconbridge Ltd. started exploration in the Cordillera in 1979, they did so in collaboration with Charles E. Fipke (figure 7, left) operating as C. F. Minerals Research Ltd. The exploration was directed by Hugo Dummett (Superior Oil). Dr. Stewart L. Blusson (figure 7, right), a long-time acquaintance of Fipke, assisted with sampling between 1981 and 1983 (Fipke et al., 1995b). In late summer 1982, Fipke and Blusson sampled, in secrecy, in the vicinity of Blackwater Lake (figure 8) after Dummett learned that De Beers had claims in that area. Fipke and Blusson made the important observation that the glacial tills in the Blackwater Lake area contained debris that suggested a source from rocks of the Precambrian Shield to the east. This was the beginning of the exploration that ultimately led to the discovery of the Lac de Gras kimberlite field.

By 1982, however, both Falconbridge and Superior had ceased exploration for diamonds in Canada. They transferred their assets (e.g., claims near Mountain diatreme and the Blackwater Lake data) to Fipke and Blusson, who then formed a 50-50 diamond exploration partnership known as the Blackwater Group. Without financial support from Falconbridge and Superior, however, they were unable to fund expensive exploration in the field and advanced instrumentation in the laboratory. In 1983, Fipke formed Dia Met Minerals Ltd., which went 
public in 1984, to finance additional sample collection and analytical activities. Blusson worked closely with Fipke on conceptual, planning, and tactical aspects of the exploration and retained his financial interest in future discoveries.

For the rest of the decade, Fipke and Blusson explored eastward from Blackwater Lake into the "Barren Lands," the name given to the vast (roughly 500,000 sq. mi. [1.3 million $\left.\mathrm{km}^{2}\right]$ ), bleak, remote areas of northern Canada. The Barren Lands characteristically have few trees but numerous lakes and bare rock that is variably covered with a veneer of glacial deposits. In 1983, Fipke and Blusson discovered that the regional sampling procedures (i.e., obtaining indicator minerals primarily from stream sediment samples) that they had used previously in areas such as the Cordillera were ineffective in the region north of Lac la Martre. This is because the Barren Lands contain too many lakes and too few rivers, in an immature drainage network. The fateful decision was then made to sample the eskers shown on Quaternary geology maps published by the Geological Survey of Canada. By 1985, float planeand helicopter-supported esker (and also till) sampling had taken them to Aberdeen Lake, far to the east of the Slave craton (again, see figure 8).

Interpretation of the results through 1985 showed that several highly anomalous indicator-mineral samples were abundant immediately north of Lac de Gras. One such sample contained $~ 10,000$ indicator

Figure 8. This map shows the prospecting route, and major geographic locations mentioned in the text, that Fipke and Blusson took from the Blackwater Lake east to the Lac de Gras kimberlite field and beyond, in the Barren Lands, NWT. After Fipke et al. (1995b).

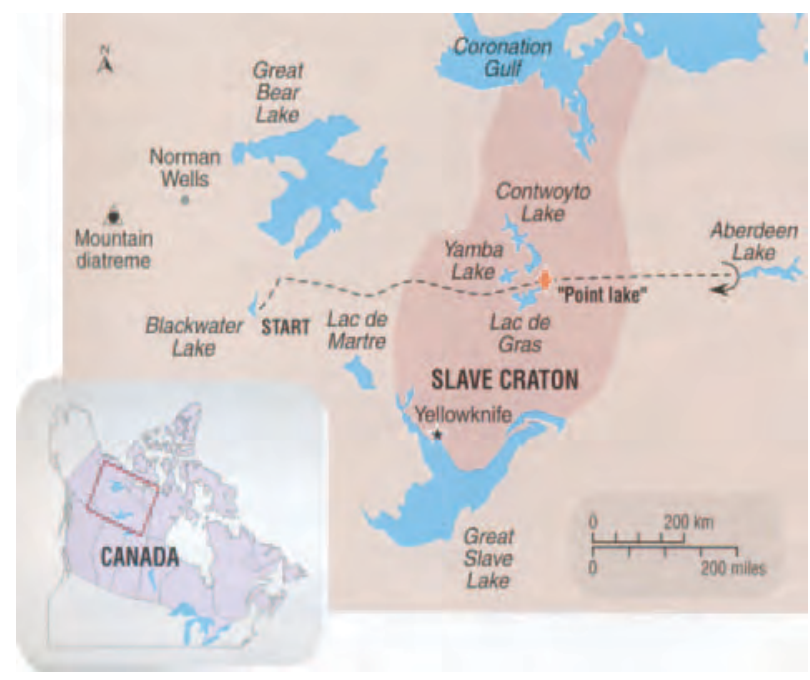

minerals (combined pyrope, chrome diopside, and ilmenite; Kraiick, 2001). Significantly, there were few such anomalous samples east of Lac de Gras. This suggested the source area had been located. Following extensive sampling, in 1989 Dia Met Minerals (usually under the name of others) began to stake claims in the Lac de Gras area that totaled nearly 350,000 ha by 1995 (Fipke et al., 1995b). All the while, Fipke and Blusson were only one step ahead of other diamond exploration programs, including those of De Beers and Selco. Further details of the exploration activities that led to Dia Met's discovery of the Lac de Gras kimberlite field can be found in Fipke et al. (1995b), Duval et al. (1996), Boyd (1998), "The Ekati Diamond Mine" (1998), Frolick (1999), and especially Krajick (2001).

\section{0-2002: SUCCESS AT LAST}

The 1990s will be remembered as the decade in which exploration activity led to the discovery of a great number of diamond-bearing kimberlites in Canada. These discoveries were made throughout the country, particularly in the NWT and Nunavut (a territory created from the NWT on April 1, 1999), but also in Ontario, Saskatchewan, Quebec, and Alberta. The world-class Ekati Diamond Mine ${ }^{\mathrm{TM}}$ opened in 1998, with the Diavik mine slated to begin production in early 2003 (figure 9). Several other projects are currently at an advanced exploration, feasibility, or permitting stage.

The Ekati Diamond Mine, Lac de Gras. In 1990, on the shore of a small lake called "Point lake" (a name chosen specifically to confuse other diamond explorers, as the real Point Lake lies $200 \mathrm{~km}$ to the northwest), Dia Met took a sample that yielded numerous indicator minerals with compositions indicating a diamondiferous kimberlite source (Fipke et al., 1995b). In September of that year, BHP formed a joint venture with Dia Met, Fipke, and Blusson-the NWT Diamonds Project - to explore, develop, and mine in the NWT. The agreement called for BHP to fund the diamond exploration program and, by spending up to US\$500 million on future mine construction costs on behalf of the consortium, BHP would earn $51 \%$ of equity in the project; the remaining equity would be Dia Met $29 \%$, Fipke $10 \%$, and Blusson $10 \%$. The diamond exploration industry worldwide was startled because of the large amount of money involved, which valued the future mine, if any, at more than US\$1 billion. (Note that through- 


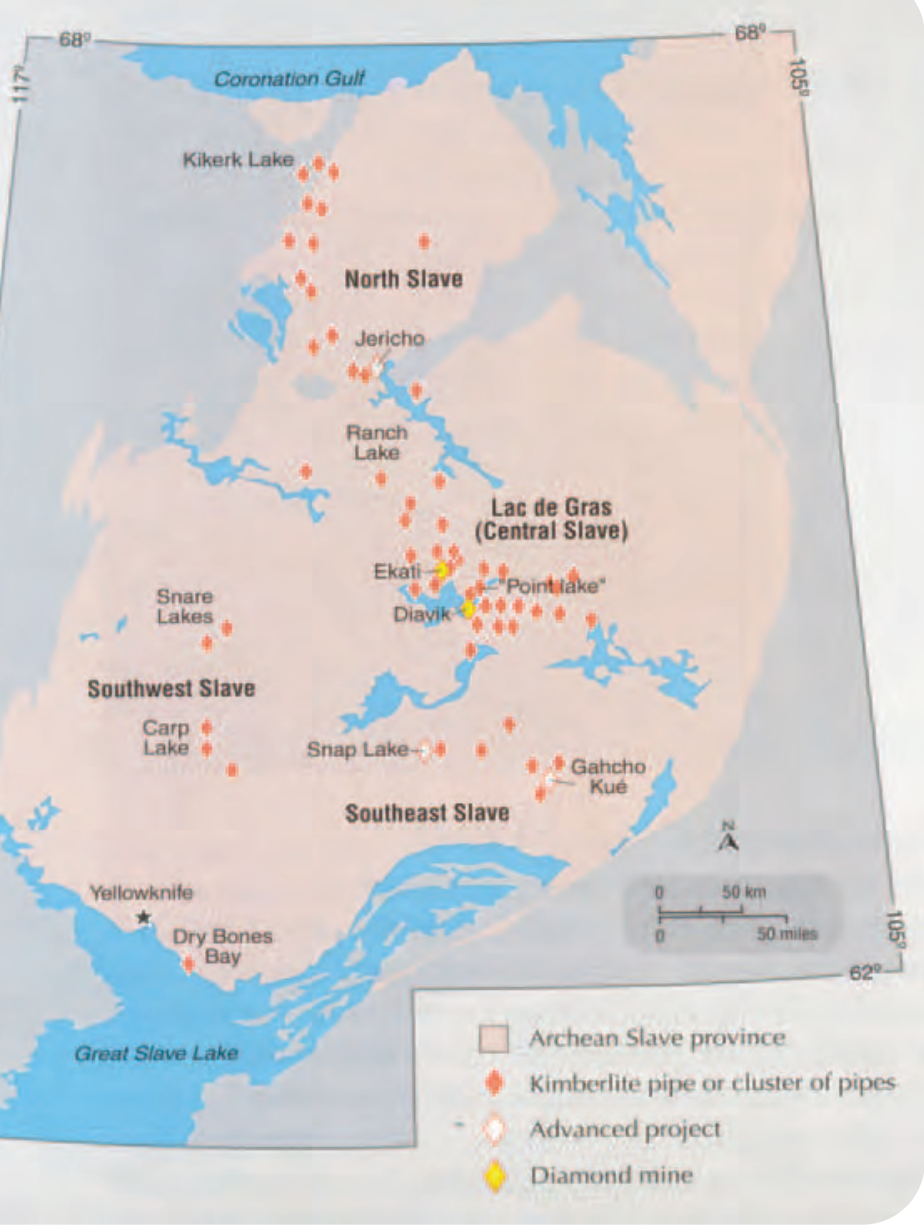

Figure 9. Numerous kimberlites are found within the Slave craton. Four important kimberlite fields in the craton are shown here: Central (or Lac de Gras, with the Ekati and Diavik mines), Southeast (with the Snap Lake and Gahcho Kué projects),

Southwest, and North (with the Jericho project).

out the balance of this article, dollar amounts are given in U.S. dollars unless otherwise indicated as Canadian dollars [Can\$].) BHP also retained the responsibility to market future diamond production. Dia Met (under the supervision of Fipke) continued to manage the exploration project until July 1993 (J. A. Carlson, pers. comm., 2002).
In May 1991, BHP conducted geophysical surveys around and over "Point lake." That September, the joint venture drilled from the shore of "Point lake" and intersected kimberlite under the lake. Two months later, Dia Met announced this discovery and released the diamond recovery results $(81$ diamonds consisting of 65 microdiamonds and 16 macrodiamonds, from $59 \mathrm{~kg}$ of kimberlite; "The Ekati Diamond Mine," 1998). This announcement triggered one of the greatest staking rushes the world has ever experienced. By the end of 1992, at least 50 companies had staked almost 8 million hectares in the NWT (Levinson et al., 1992). Almost simultaneously, the methods of diamond exploration that were instrumental in finding the "Point lake" kimberlite (geophysical surveys, and the recognition and significance of kimberlite indicator minerals, combined with the use of eskers and tills for sampling) became widely known. By 1994, more than $80 \%$ of the Slave craton $\left(20,000,000\right.$ ha or $\left.200,000 \mathrm{~km}^{2}\right)$ had been staked by over 100 companies (Pell, 1994).

In early 1992, bulk sampling of the "Point lake" kimberlite yielded a diamond content of 0.63 ct/tonne and a stone value of $<\$ 40 /$ ct, which rendered this pipe subeconomic (Fipke et al., 1995b; "The Ekati Diamond Mine," 1998). That same year, however, nine additional kimberlites were discovered in the Lac de Gras area, including the Fox and Koala pipes (now in the current Ekati mine plan). The Panda and Misery pipes (currently in production; see figure 10) were discovered in 1993. By the end of 1994, a total of 39 kimberlites were known in the Lac de Gras area, most of which were under lakes (Carlson et al., 1995). At the same time, Fipke et al. (1995b) reported that all but one of these 39 kimberlites were diamond bearing.

By late 1993, it was clear that several kimberlites at Lac de Gras were probably economic, including the Fox (16.4 million tonnes of kimberlite; grade 0.3 ct/tonne; $\$ 129 / \mathrm{ct}$ ) and Koala (12.1 million tonnes of kimberlite; grade varies from 0.9 [pit] to 1.5 [underground] ct/tonne; $\$ 138 / \mathrm{ct}$ ) pipes (Kjarsgaard et al., 2002). Starting in 1993, the joint-venture partners

Figure 10. The Lac de Gras area contains the most important Canadian diamond deposits recognized so far.

The locations of the economic pipes at the Ekati and Diavik mines are shown. The Panda pit (top, looking south, taken in August 2001) is the first of several economic pipes that will come into production sequentially over the life of the Ekati mine. In the immediate background, pre-stripping of the Koala pit can be seen.

The development of the Misery pit is shown in the center photo, taken in August 2001. Both photos and the map are courtesy of BHP Billiton Diamonds Inc. At the Diavik mine (bottom, looking northwest, taken in September 2002), a retaining dike system has been constructed in the area surrounding the A-154N and A-154S pipes. Most of the water has been pumped out. Photo courtesy of Diavik Diamond Mines Inc. 


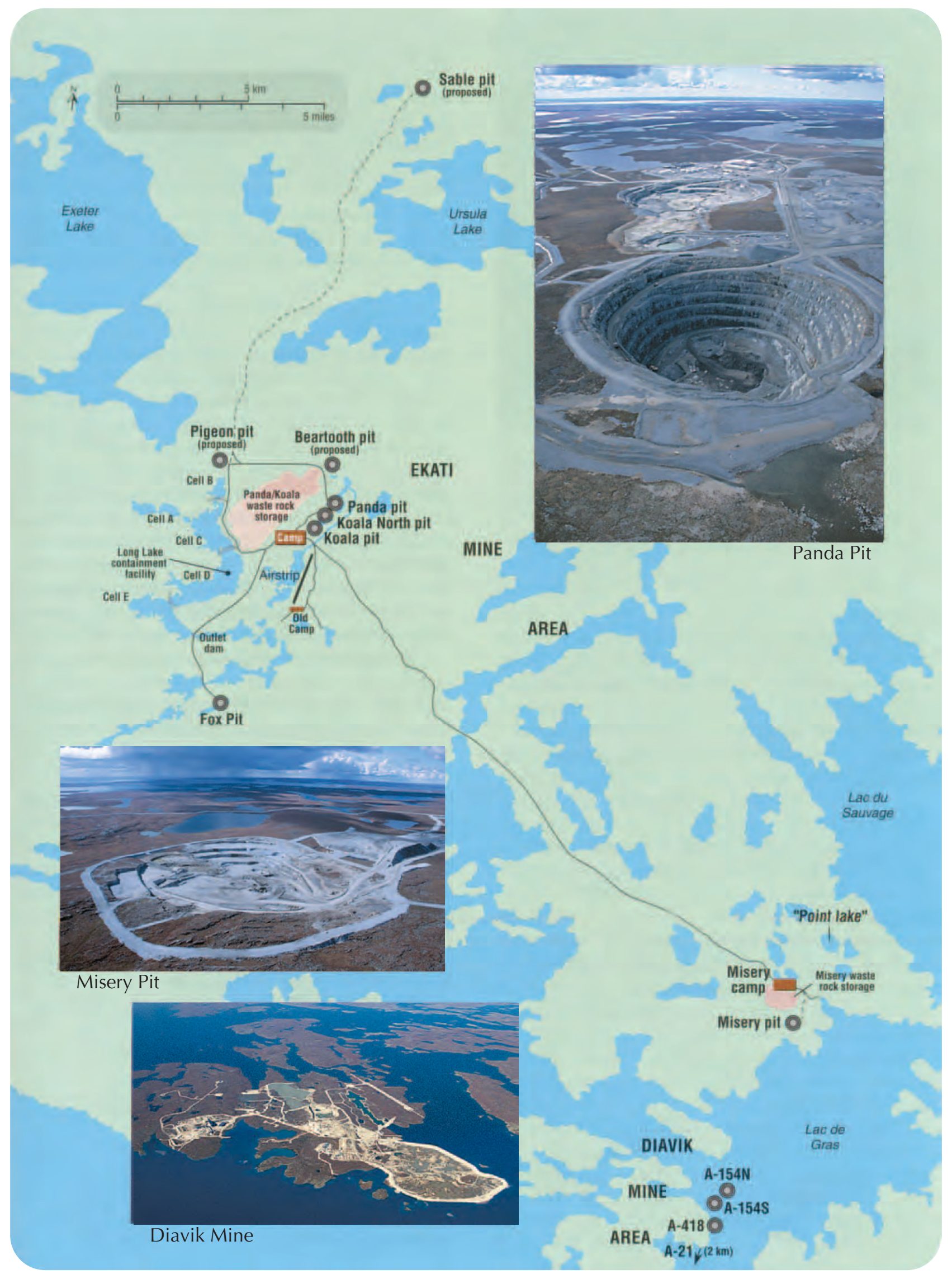




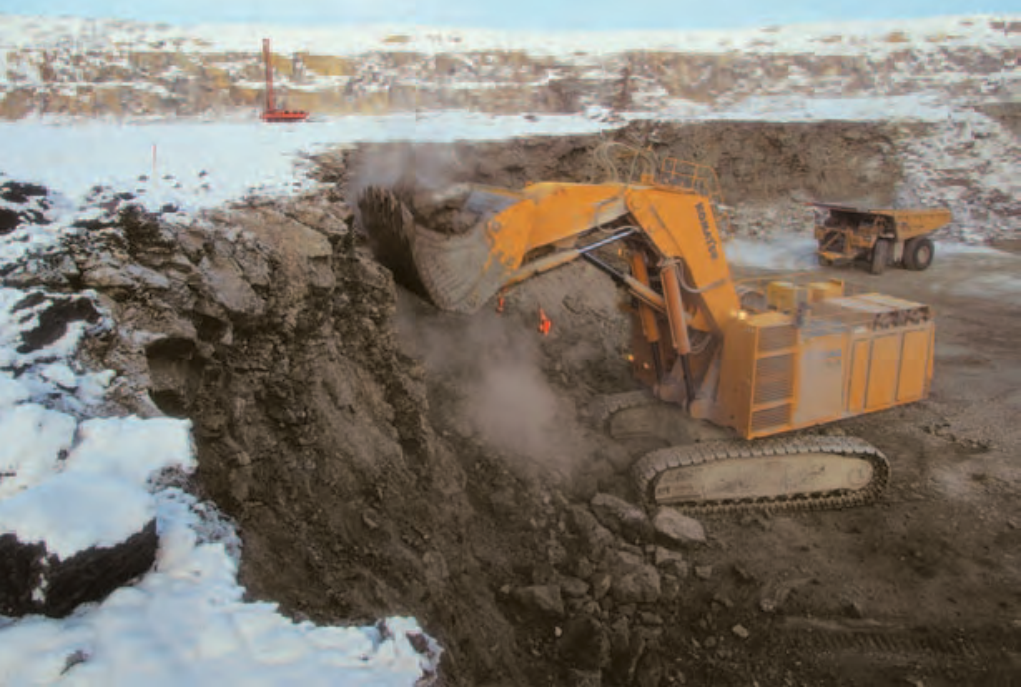

Figure 11. Shown here in winter 1998, diamond mining at Ekati's Panda pit is done with large excavators and trucks. The truck in the background can carry 240 tonnes of rock. Courtesy of BHP Billiton Diamonds Inc.

went through what at the time was "the most exhaustive environmental, economic and social review in the history of Canadian mining" ("The Ekati Diamond Mine," 1998, p. 26), because the kimberlites are located in one of the most pristine and ecologically sensitive areas of Canada. Approval for the project was received in July 1996, after a review process involving many agencies, including the federal Department of Indian and Northern Affairs, the Government of the Northwest Territories, and four aboriginal groups. Construction of the mine began in January 1997. In September of that year, the NWT Diamonds Project was officially renamed the Ekati Diamond Mine, which today is trademarked. Ekati is the indigenous name for Lac de Gras, both of which mean fat lake. It refers to the abundant light-colored pegmatite stringers, veins, and dikes that cross-cut granites around the shores of the lake, like white fat running through caribou meat.

Construction of the Ekati mine was an amazing engineering and logistical feat in view of the numerous challenges presented by the remoteness of the area, the lack of permanent roads (a $475 \mathrm{~km}$ ice road is available from Yellowknife for only $8-10$ weeks from mid-January to mid-April), the lack of other types of infrastructure (e.g., electricity), and the harsh climate (temperatures can drop to $-50^{\circ} \mathrm{C}$ in the winter months). Yet, construction of a processing plant and supporting facilities, as well as prepara- tion of the first kimberlite (figure 11), were completed on schedule in 21 months. Further, from the initial discovery of diamonds at "Point lake" in late 1991 through the feasibility studies and environmental approvals, it was only seven years to the official opening of the Ekati mine on October 14, 1998. This is a remarkable achievement. The mine employs about 680 people; $79 \%$ are residents of the NWT and $40 \%$ are aboriginal (Williams and Carlson, 2001).

The Ekati mine was located originally on a land lease of 10,960 ha, which has since been extended to 344,000 ha. It cost about $\$ 700$ million to construct. The Panda pipe was the first kimberlite mined (for details, see Johnson and Koivula, 1998; Krajick, 2001). In 1999, the first year of full production, this worldclass mine produced 2.4 million carats (Mct) of rough diamonds worth $\$ 408$ million (table 2). This made Canada the world's seventh largest diamondproducing country in terms of both weight and value. Ekati's Panda pipe was the world's fourth most valuable diamond mine (Rombouts, 2000), exceeded that year only by Jwaneng (Botswana), Udachnaya (Russia), and Argyle (Australia). A variety of cuts and colors of polished diamonds from Ekati are shown in figure 12.

Throughout this period, the Ekati group continued to explore for additional kimberlite pipes in its claim area. By the end of 2001, they had identified a total of 146 pipes (table 3). Reserves at the start of mining were 72 Mct of rough diamonds and 66 million tonnes of kimberlite (average grade 1.09 ct/tonne), from several pipes (Johnson and Koivula, 1998, Gonzales et al., 2000). Current reserves are 52.8 Mct of rough diamonds from 58.2 million tonnes of kimberlite (average grade of $0.91 \mathrm{ct} /$ tonne), from six pipes (BHP Billiton 2002 Annual Report). Initially,

\begin{tabular}{|c|c|c|c|c|}
\hline Production & 1998 & 1999 & 2000 & 2001 \\
\hline Carats & 203,000 & 2,428,783 & $2,435,036$ & $3,685,171$ \\
\hline $\begin{array}{l}\text { Total value } \\
\text { Can\$ } \\
\text { US\$ }\end{array}$ & $\begin{array}{l}40,775,000 \\
27,482,350\end{array}$ & $\begin{array}{l}606,254,000 \\
408,008,940\end{array}$ & $\begin{array}{l}624,949,000 \\
429,482,350\end{array}$ & $\begin{array}{l}846,925,000 \\
531,022,000\end{array}$ \\
\hline $\begin{array}{l}\text { Value per car } \\
\text { Can\$ } \\
\text { US\$ }\end{array}$ & $\begin{array}{l}201 \\
135\end{array}$ & $\begin{array}{l}250 \\
168\end{array}$ & $\begin{array}{l}257 \\
173\end{array}$ & $\begin{array}{l}230 \\
144\end{array}$ \\
\hline $\begin{array}{l}\text { a Source of } \\
\text { www.nrcan.g } \\
\text { Conversion } \\
2000=0.67\end{array}$ & $\begin{array}{l}\text { : Natural Res } \\
\text { /mms/efab/m } \\
\text { for Can } \$ \text { to } \\
001=0.627\end{array}$ & $\begin{array}{l}\text { urces Canada: } \\
\text { sd; } 2001 \text { figure } \\
\text { IS\$: } 1998=0 .\end{array}$ & $\begin{array}{l}\text { are preliminar } \\
74 ; 1999=0\end{array}$ & \\
\hline
\end{tabular}




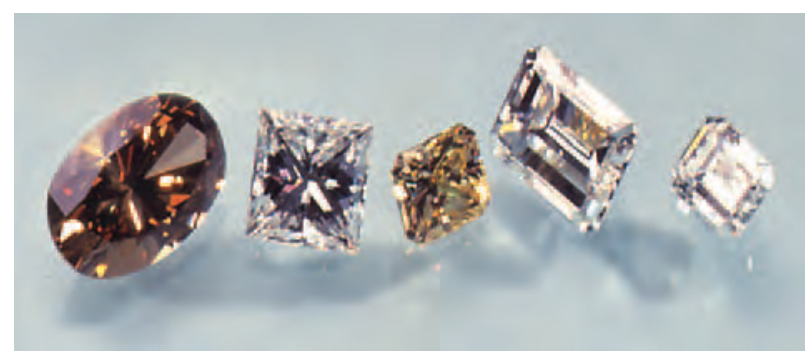

Figure 12. These diamonds from the Panda pit show a representative color range of diamonds produced at the Ekati mine. Courtesy of BHP Billiton Diamonds Inc.

Ekati held permits to mine the Panda, Koala, Misery, and Fox kimberlites. In December 1998, the company applied for additional permits to develop the Sable, Pigeon, and Beartooth pipes (Markovic, 1999). Resources identified to date will enable the mine to operate until at least 2016. In May 2001, BHP (now BHP Billiton) acquired Dia Met, raising its ownership in the Ekati Diamond Mine to $80 \%$. Fipke and Blusson each retains $10 \%$ interest. Currently, the mine is producing from both the Panda and Misery pipes. There is underground production from a test mine at the Koala North pipe, and pre-stripping has begun at the Koala pipe (again, see figure 10), which will soon be the next major feed source (Janse, 2002).

The Diavik Project, Lac de Gras. Aber Resources Ltd. was one of the first companies to start staking claims in the Lac de Gras area in November 1991, shortly after Dia Met announced its success at "Point lake." This small Canadian exploration company staked claims south and east of the "Point lake" discovery and adjacent to the original Dia Met (now Ekati) claims (again, see figures 9 and 10). In June 1992, Rio Tinto agreed to finance Aber's exploration in exchange for the right to earn a $60 \%$ interest in certain Aber claims. That same year, Aber discovered eight kimberlites. The four most important kimberlites discovered by Aber (A-154 South, A-154 North, A-418, and A-21, which would constitute the future Diavik mine) were found in 1994 and 1995 in the shallow waters of Lac de Gras. In November 1996, Aber and Rio Tinto formed the Diavik Diamonds Project, a joint venture of Diavik Diamond Mines Inc. (60\%; wholly owned by Rio Tinto) and Aber Diamond Mines Ltd. (40\%; wholly owned by Aber Diamond Corp. [formerly Aber Resources Ltd.]). Diavik Diamond Mines is the manager of the project. Each participant retained the right to market its respective share of the diamond production independently.
Between 1994 and 1996, evaluation of the kimberlite grade and diamond value revealed that a mine was viable. When in full operation, the mine will produce approximately 6 million carats (Mct) annually for about 20 years, with an average value

TABLE 3. Number of kimberlites reported in Canada, as of September 2002.

\begin{tabular}{|c|c|}
\hline Location & Number \\
\hline \multicolumn{2}{|l|}{ NWT and Nunavut } \\
\hline \multicolumn{2}{|l|}{ Central Slave Craton (Lac de Gras, NWT) } \\
\hline Ekati claim area & 146 \\
\hline Diavik claim area & 58 \\
\hline De Beers (Hardy Lake) & 20 \\
\hline Others & 23 \\
\hline \multicolumn{2}{|l|}{ Southeast Slave (NWT) } \\
\hline Snap Lake, Gahcho Kué, others & 14 \\
\hline \multicolumn{2}{|l|}{ Southwest Slave (NWT) } \\
\hline Carp Lake, Dry Bones Bay, others & 15 \\
\hline \multicolumn{2}{|l|}{ Far Northwest Slave (NWT) } \\
\hline Darnley Bay & 10 \\
\hline \multicolumn{2}{|l|}{ North Slave (Nunavut) } \\
\hline Jericho and Coronation Gulf area & 23 \\
\hline \multicolumn{2}{|l|}{ Victoria Island (NWT and Nunavut) } \\
\hline De Beers, others & 17 \\
\hline Total for Slave Craton & $\overline{326}$ \\
\hline \multicolumn{2}{|l|}{ Churchill Craton (Nunavut) } \\
\hline Somerset Island & 20 \\
\hline North Baffin Island and Brodeur Peninsula & 5 \\
\hline Rankin Inlet & 3 \\
\hline Total for Churchill Craton & $\overline{28}$ \\
\hline TOTAL for NWT and Nunavut & $\overline{354}$ \\
\hline \multicolumn{2}{|l|}{ Other Parts of Canada } \\
\hline \multicolumn{2}{|l|}{ Alberta } \\
\hline Buffalo Hills & 36 \\
\hline Birch Mountains & 8 \\
\hline \multicolumn{2}{|l|}{ Saskatchewan } \\
\hline Fort à la Corne & 74 \\
\hline \multicolumn{2}{|l|}{ Ontario } \\
\hline Kirkland Lake & 14 \\
\hline Lake Timiskaming & 12 \\
\hline Attawapiskat & 19 \\
\hline Kyle Lake & 5 \\
\hline \multicolumn{2}{|l|}{ Quebec } \\
\hline Lake Timiskaming & 3 \\
\hline Otish Mountains & 7 \\
\hline Wemindji & 1 \\
\hline \multicolumn{2}{|l|}{ Manitoba } \\
\hline Snow Lake-Wekusko & 1 \\
\hline \multicolumn{2}{|l|}{ British Columbia } \\
\hline Cross, others & 4 \\
\hline TOTAL for other parts of Canada & 184 \\
\hline GRAND TOTAL for Canada & $538^{a}$ \\
\hline
\end{tabular}

aThe number of kimberlites should be considered a minimum because it is not required that companies report their kimberlite discoveries. 
of $\$ 63 /$ ct (table 4; based on 2000 valuation estimates). The Diavik kimberlites, like most in the Slave craton, are small $(<3 \mathrm{ha})$, but their grades of $\sim 4$ ct/tonne (range 3.0-5.2 ct/tonne) are three to four times higher than those in most other major producing mines (Burgess, 2001; Kjarsgaard et al., 2002). Thus, when the Diavik mine is in full production, it will have the highest ore value ( $\$ 252 /$ tonne $[\$ 63 \times 4])$ of any primary diamond mine in the world. This is particularly true for the A-154 South pipe, which averages $5.2 \mathrm{ct} /$ tonne of diamonds valued at $\$ 79 /$ ct (for a total ore value of $\$ 410 /$ tonne).

After extremely detailed examination of the environmental aspects of the proposed $\$ 830$ million mine, Diavik obtained permits and licenses to begin construction in November 1999 ("Diamond Facts 2000/01," 2001). Since the kimberlites lie under the shallow waters of Lac de Gras, a retention dike system is required to mine them (again, see figure 10). During 2000-02, construction of the mine has proceeded ahead of schedule (figure 13). The mine plan calls for a two-year ramp-up period, starting in early 2003, before full production is achieved. Some of the stones recovered during the evaluation stage already have been cut and set in fine jewelry (figure 14).
Other Advanced Projects in NWT and Nunavut. Both industry and government (e.g., Paget, 1999) agree that three projects in the NWT and Nunavut-Snap Lake, Gahcho Kué, and Jerichoare at an advanced stage of evaluation or development and may have the potential to become mines (table 4). However, actual construction of another mine has not yet begun.

Snap Lake Project. Indicator minerals in glacial till, as well as kimberlite boulders, were identified from the Snap Lake area (figures 2 [12] and 9) in 1995-96 by a joint venture between Winspear Resources (initially $57.3 \%$, subsequently $67.76 \%$ ) and Aber Resources Ltd. (initially $42.7 \%$, subsequently $32.24 \%$ ). In 1997, an outcrop of the diamond-bearing kimberlite dike, covered by a thin layer of till, was located on the west shore of Snap Lake. Subsequent sampling showed it to be potentially economic (table 4). The kimberlite, a shallow-dipping dike averaging $2.5 \mathrm{~m}$ thick, covers an area of $2.5 \mathrm{~km}^{2}$ (Turner and McConnell, 2001).

Snap Lake would be the first entirely underground diamond mine in Canada, and as such will have a much smaller "footprint" than an open-pit mine; moreover, it is land based. It would also be

TABLE 4. Diamond mines under construction and advanced diamond projects ${ }^{\mathrm{a}}$ in Canada.

\begin{tabular}{|c|c|c|c|c|c|}
\hline Project name & Location & Owner & Reserves & Comments & References \\
\hline \multicolumn{6}{|l|}{ Under construction } \\
\hline Diavik & NWT & $\begin{array}{l}\text { Diavik Diamond Mines } \\
\text { (60\%, Rio Tinto) and } \\
\text { Aber Diamond Mines } \\
\text { (40\%, Aber Diamond Corp.) }\end{array}$ & $\begin{array}{l}25.6 \text { million tonnes of kimber- } \\
\text { lite with 4 ct/tonne (102 Mct) } \\
\text { at } \$ 63 / c t\end{array}$ & $\begin{array}{l}\text { Production expected in early } \\
2003 \text {; estimated to produce } \\
\sim 6 \mathrm{Mct} / \mathrm{yr} \text { when in full } \\
\text { production }\end{array}$ & $\begin{array}{l}\text { www.diavik.ca, } \\
\text { www.aber.ca }\end{array}$ \\
\hline \multicolumn{6}{|l|}{ Advanced projects } \\
\hline Snap Lake & NWT & De Beers (100\%) & $\begin{array}{l}22.8 \text { million tonnes of kimber- } \\
\text { lite with } \sim 2.0 \mathrm{ct} / \text { tonne }(\sim 45 \mathrm{Mct}) \\
\text { at } \sim 100 / \mathrm{ct}\end{array}$ & $\begin{array}{l}\text { Kimberlite dike } 2.5 \mathrm{~m} \text { thick } \\
\text { delineated over area } 2.5 \times 2.5 \mathrm{~km} \text {; } \\
\text { production scheduled to begin in } \\
2006\end{array}$ & $\begin{array}{l}\text { Turner and McConnell } \\
\text { (2001), Laurs (2001), } \\
\text { Natural Resources } \\
\text { Canada (2002) }\end{array}$ \\
\hline $\begin{array}{l}\text { Gahcho Kué (Kennady } \\
\text { Lake)_Hearne and } \\
5034 \text { kimberlites }\end{array}$ & NWT & $\begin{array}{l}\text { De Beers (51\%), } \\
\text { Mountain Province }(44.1 \%) \text {, } \\
\text { Camphor Ventures (4.9\%) }\end{array}$ & $\begin{array}{l}\text { Hearne: } 6.86 \text { million tonnes of } \\
\text { kimberlite with } 1.71 \mathrm{ct} / \text { tonne } \\
(11.7 \mathrm{Mct}) \text { at } ~ \$ 63 / \mathrm{ct} \\
5034: 12.5 \text { million tonnes of } \\
\text { kimberlite at } 1.64 \mathrm{ct} / \text { tonne } \\
(\sim 21 \mathrm{Mct}) \text { at } \$ 65 / \mathrm{ct}\end{array}$ & $\begin{array}{l}\text { Deposit is subeconomic } \\
\text { (by } 15 \% \text { ) at present }\end{array}$ & www.mountainprovince.com \\
\hline Jericho & Nunavut & $\begin{array}{l}\text { Tahera ( } 100 \%) \text {; Rio Tinto } \\
\text { has various options including } \\
62.5 \% \text { ownership }\end{array}$ & $\begin{array}{l}2.5 \text { million tonnes of kimber- } \\
\text { lite with } \sim 1.2 \mathrm{ct} / \text { tonne }(3 \mathrm{Mct}) \\
\text { at } \sim 80 / \mathrm{ct}\end{array}$ & $\begin{array}{l}\text { Kimberlite grade and diamond } \\
\text { value are satisfactory, but } \\
\text { reserves are problematic }\end{array}$ & www.tahera.com \\
\hline Victor & $\begin{array}{l}\text { Attawapiskat, } \\
\text { Ontario }\end{array}$ & De Beers $(100 \%)$ & $\begin{array}{l}36.2 \text { million tonnes of kimber- } \\
\text { lite valued at } \$ 94 / \text { tonne; } \\
\text { older reports indicate grade of } \\
0.32 \text { ct/tonne }\end{array}$ & $\begin{array}{l}\text { Most advanced project outside } \\
\text { of NWT }\end{array}$ & $\begin{array}{l}\text { www.debeerscanada.com, } \\
\text { Robertson (2002f), } \\
\text { Wood (2002) }\end{array}$ \\
\hline
\end{tabular}

a Advanced diamond projects are those at the evaluation or development stage. All values are in U.S. dollars. 


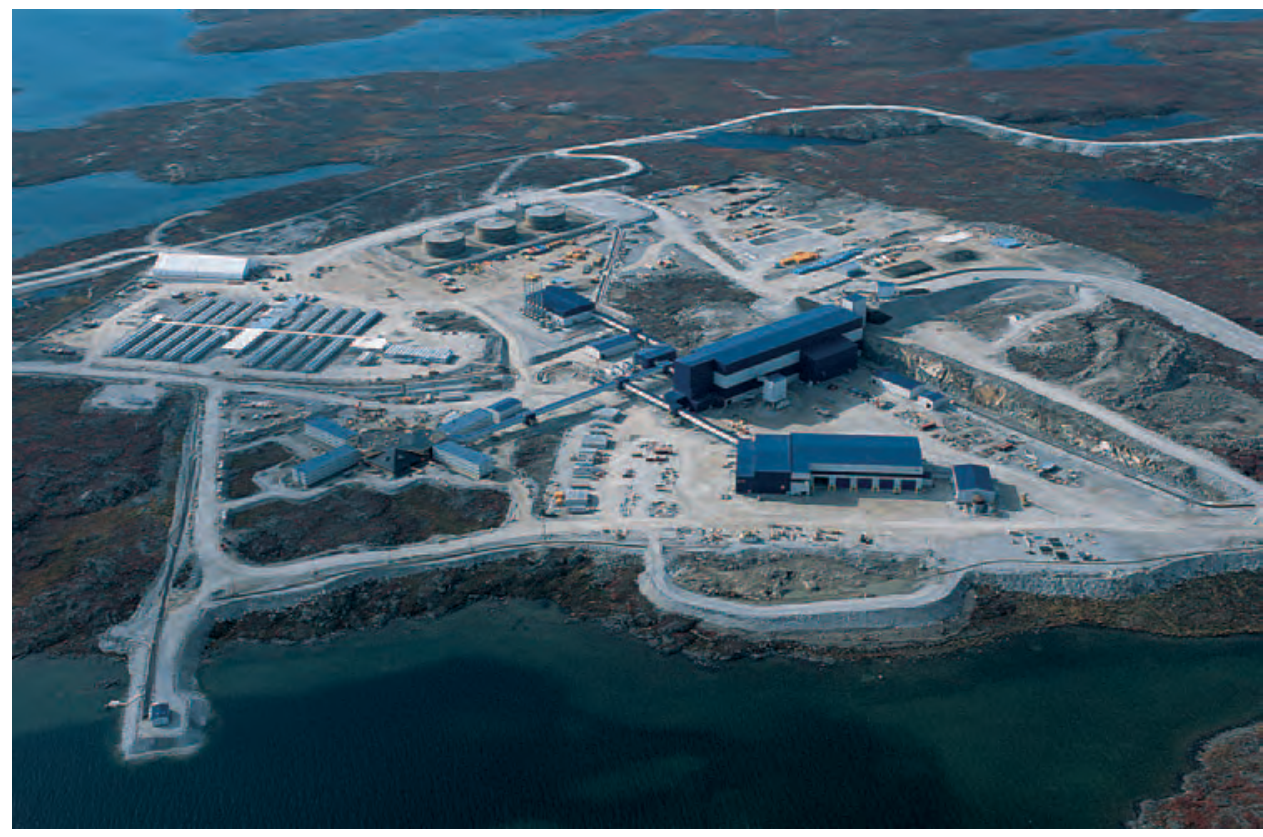

Figure 13. This aerial view of the Diavik mine was taken in September 2002. The large (11 story) building in the center is the processing facility, where diamonds will be separated from the kimberlite host rock. The building to the lower right serves as the maintenance and administration center. In the lower left is the permanent accommodations facility, and above it (with the smoke stacks) is the power plant. Photo by Jiri Hermann; courtesy of Diavik Diamond Mines Inc.

the first diamond mine in the world to begin with an underground operation and not with an open pit. In 2000-01, De Beers acquired the property. It has since applied for regulatory approval to develop the mine (figure 15), with production scheduled to begin in 2006 (Laurs, 2001).

Gahcho Kué (Kennady Lake) Project. In 1995-96, a joint venture between Mountain Province Resources (now Mountain Province Diamonds) at 90\% and Camphor Ventures at 10\% discovered several kimberlites in the Kennady Lake area (figures 2 [13] and 9). In 1997, the property was optioned to De Beers, which can earn up to $60 \%$ interest by taking the project to commercial production; currently it has $51 \%$. Eight diamondiferous kimberlites and several dikes and sills have been found on the property to date. The two most valuable kimberlites, Hearne and 5034, at present do not have the combined reserves and ore values (table 4) needed for economic development. However, De Beers continues to bulk sample these two pipes because some large ( 10 ct; figure 16) stones have been recovered and because their grade and ore value is close to the economic threshold. De Beers is also exploring for other kimberlites in the area (www.mountainprovince.com).

Jericho Project. Joint-venture partners Lytton Minerals and New Indigo Resources discovered the Jericho kimberlite pipe (JD/OD-1; 1.2 ha) in 1994 in what is now part of the Contwoyto Lake kimberlite field (figures 2 [7] and 9). In 1999, these companies merged to form Tahera Corp. As reported on the
Tahera Web site (www.tahera.com), the deposit has yielded large stones $(5-25 \mathrm{ct}$, including one $23.89 \mathrm{ct}$ piece of gem-quality rough. Feasibility studies indicate that this kimberlite could produce a total of 3 Mct of diamonds (table 4) over eight years.

The economics of a mine based solely on the resources of the small JD/OD-1 pipe alone are marginal. However, they could be improved considerably with the discovery of additional resource tonnage, which is possible since the area contains other

Figure 14. Diamonds from the Diavik project (here, the larger stone is approximately $1 \mathrm{ct}$ ) have been set into attractive gold jewelry. Courtesy of Diavik Diamond Mines Inc.

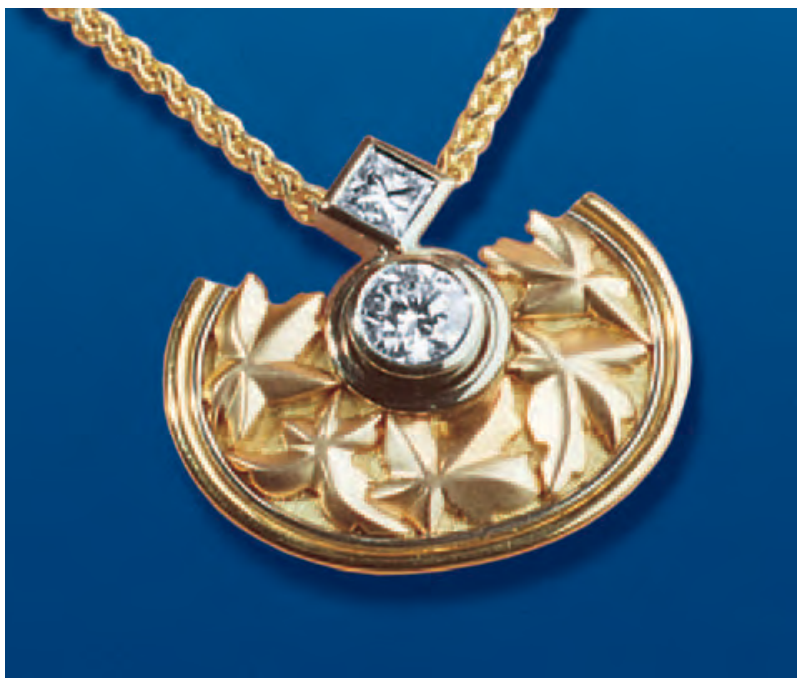




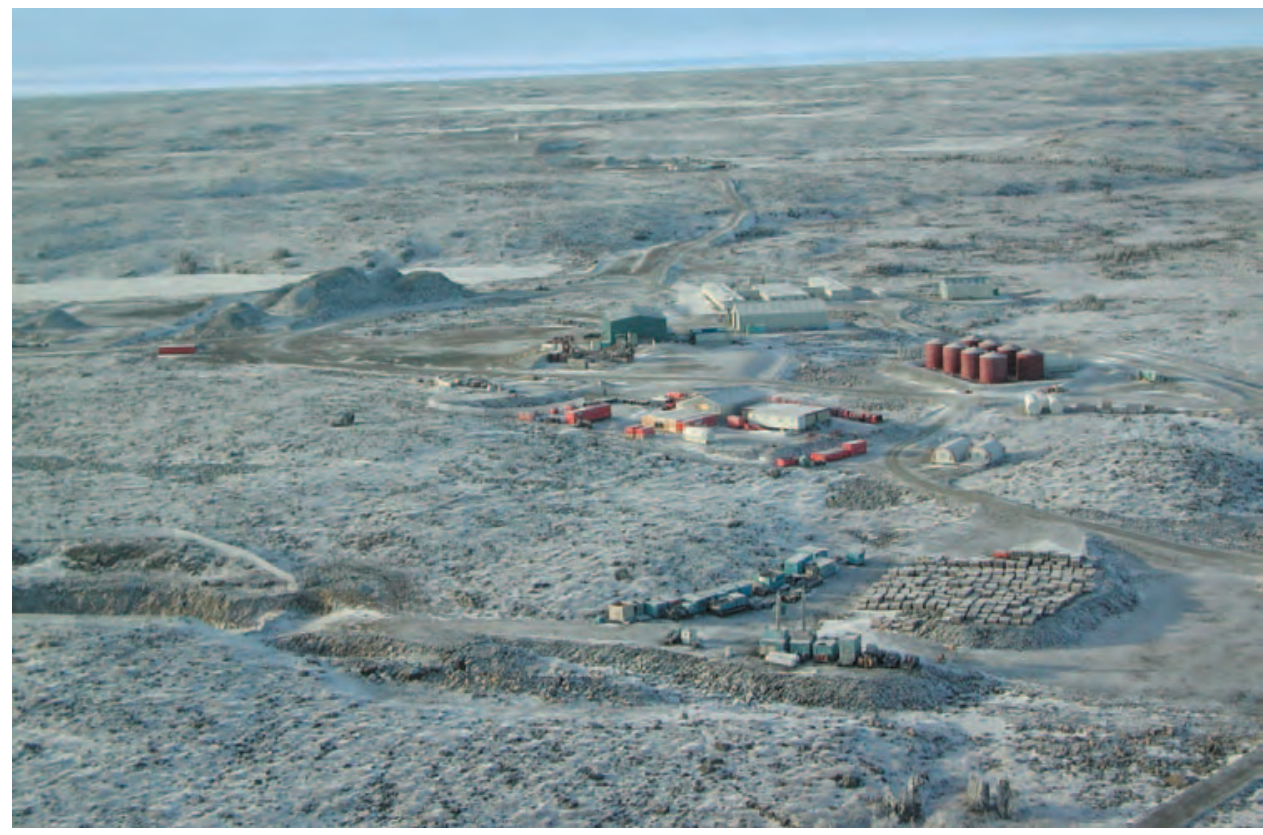

Figure 15. This image of the Snap Lake project, looking southwest, was taken in October 2001. The rock pile on the left rear is an ore stockpile, and the green building is the processing plant. The white buildings house offices and accommodations. The portal to the underground workings is located just to the left foreground of the processing plant, near the elongate orange contain er. Courtesy of De Beers Canada.

kimberlites (Janse, 2002). On the assumption that additional economic kimberlites will be found, Tahera is seeking regulatory approval for the development of the Jericho diamond mine. Rio Tinto, currently a joint-venture partner with Tahera, is the operator of the project and has certain valuable options with regard to the property (e.g., the right to market all production for the first five years). If Jericho is developed, it will be the first diamond mine in Nunavut.

Other Activities in NWT and Nunavut. As of September, 2002, at least 354 kimberlites were known in the NWT and Nunavut (table 3), several of which (in addition to the three advanced projects discussed above) are currently being evaluated. In view of this volume of discoveries, and the number of properties or fields in various stages of exploration and development within the Archean Slave craton, we can briefly mention only a few here.

De Beers discovered more than 40 kimberlites in the central and southern parts of the Slave craton during the diamond exploration boom of the 1990s, although the precise discovery dates have not been released. In addition to the eight kimberlites found to date in the Gahcho Kué area, these include 20 in the Hardy Lake area of the Lac de Gras field $(35 \mathrm{~km}$ northeast of the Ekati mine; McKinlay et al., 1998), as well as four in the Carp Lake area and five in the Snare Lakes area (figures 2 [10/11] and 9; J. A. Armstrong, pers. comm., 2002).

In the northern part of the Slave province, De Beers discovered four kimberlites between
Contwoyto Lake (Jericho area) and the Coronation Gulf on the Arctic coast in the mid-1990s (figure 9; J. A. Armstrong, pers. comm., 2002). As geologists realized the diamond potential of this area, the entire region was staked, and exploration by Ashton, Rio Tinto, and many other companies laid the groundwork for additional kimberlite discoveries (Janse, 2001, 2002). At least 10 more kimberlites have been identified. Ashton found several diamondiferous pipes (e.g., Artemesia and Potentilla) near Kikerk Lake (figures 2 [6] and 9), but their grades turned out to be low $(<0.2 \mathrm{ct} /$ tonne). High expectations are now held for the diamondiferous Anuri and Anuri East pipes (about half way between Jericho and Kikerk Lake) found in 2001 by the Rio Tinto and Tahera joint venture, but their economic potential remains to be determined. Nevertheless, indicator minerals abound in the area and enthusiasm remains high for its diamond potential (Robertson, 2002b).

On Victoria Island (also part of the Slave craton; figure 2 [4]), exploration by De Beers and other companies has led to the discovery of 12 kimberlite pipes, half of which contain diamonds; De Beers withdrew from the area at the end of 1999 (Robertson, 2002e). With renewed interest in the northern part of the Slave craton, exploration on Victoria Island has also been re-invigorated, with five new diamondiferous kimberlites reported in 2002 (Robertson, 2002e).

The Ranch Lake pipe (figures 2 [8] and 9), which is the northernmost extension of the Lac de Gras kimberlite field, was discovered in 1993 by Tahera. Although this large kimberlite (12.5 ha, atypical for 
the Lac de Gras field) is diamond bearing $(0.2$ ct/tonne; Janse, 2002), it was deemed uneconomic. It is currently being re-examined by BHP Billiton (www.tahera.com).

Activities Elsewhere in Canada. Alberta. Before 1990, a few diamond discoveries were reported from various locations in glacial tills and alluvial materials in Alberta (Morton et al., 1993; Dufresne et al., 1996), but none was substantiated. Consequently, the industry was startled when in early 1991 it learned that De Beers had staked 680,000 ha in the Peace River region of Alberta (Levinson et al., 1992). This was more than $1 \%$ of the total area of the province (66.1 million ha). The impetus for the staking was what are now called the Mountain Lake ultrabasic pipes (Leckie et al., 1997; figure 2 [17]). These pipes were later determined to be only weakly diamondiferous and, therefore, uneconomic.

Massive staking by numerous companies ensued almost immediately after the De Beers activities became general knowledge (the so-called first Alberta staking rush). During 1992 alone, about one-third of the province (22.4 million ha; Dufresne et al., 1996) was staked for diamond exploration; this rose to more than 50\% by early 1994 (Kjarsgaard, 1997), primarily in western and southern Alberta. Extensive indicator mineral surveys in stream sediments and tills were conducted throughout the province, but no kimberlites or other diamond-bearing rocks were found in the early to mid-1990s. By 1995, Alberta's luster as a diamond exploration area had diminished greatly; only about 1.6 million ha were staked that year (B. Hudson, pers. comm., 2002). Subsequently, De Beers (and many other companies) relinquished their claims, and the lands reverted to the Alberta government.

Alberta is an important producer of oil and gas, and geophysical (mainly seismic and aeromagnetic) surveys are routinely conducted as part of such exploration programs. In 1995, Alberta Energy Co. Ltd. (now merged into EnCana) acquired highresolution geophysical data for parts of northern Alberta. These data revealed unusual features that bore no relation to petroleum deposits, and were interpreted as potentially related to kimberlite intrusions. This information was made available to Ashton, and in October 1996 Ashton formed a joint venture with Alberta Energy (42.5\%) and Pure Gold Resources (15\%), which staked large areas in the Buffalo Hills region (figure 2 [16]). Drilling of the anomalies started in January 1997, and by early

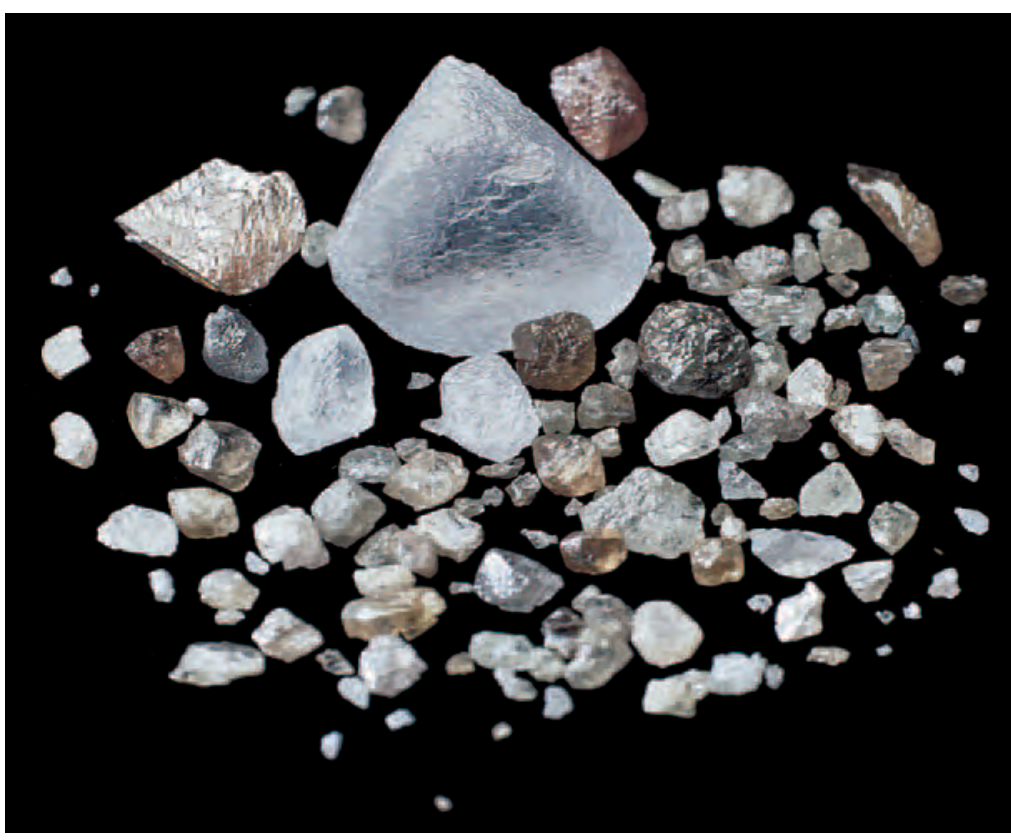

Figure 16. This parcel of rough diamonds was recovered from Gahcho Kué (5034 pipe). The largest stone weighs $9.9 \mathrm{ct}$ and is of good gem quality. Courtesy of Mountain Province Diamonds Inc.

March 11 kimberlites had been found. This set off Alberta's second staking rush, with 37.2 million ha $\left(372,000 \mathrm{~km}^{2}\right)$ staked in 1997 alone (B. Hudson, pers. comm., 2002). Claim staking by about 30 companies, including De Beers and Rio Tinto (Natural Resources Canada, 2000), occurred in the northern and central parts of the province. Rio Tinto subsequently discovered the Birch Mountains kimberlite field (figure 2 [15]), but withdrew from the area when it proved uneconomic.

By early 1999, Ashton had outlined the Buffalo Hills kimberlite field, which included 32 (now 36; table 3) kimberlites, about $60 \%$ of which contained diamonds. S. M. Carlson et al. (1999) provide geologic details of this area, including descriptions of the kimberlites and the diamonds recovered. Some of these kimberlites are large (up to $45 \mathrm{ha}$ ), and some of the diamonds are of good quality and weigh up to 1.3 ct. Nevertheless, as the 1990s came to a close the Buffalo Hills kimberlite field was generally thought to be subeconomic, although Ashton and others continued to explore in the area.

After 10 years of disappointments in Alberta, there were great expectations when Ashton found the K252 kimberlite in the Buffalo Hills in 2000. The grade of this pipe (0.54 ct/tonne) and the quality of its diamonds (figure 17) were the best so far discovered in the province. However, in early 2002 Ashton 
announced that the pipe was too small for further consideration. Also in early 2002, BHP Billiton acquired options in the Calling Lake region, about $150 \mathrm{~km}$ southeast of the Buffalo Hills area (Robertson, 2002a). The Calling Lake tills abound with indicator minerals (e.g., garnets), for which a source has yet to be identified. This activity has attracted the attention of other diamond exploration companies, which ensures that exploration for diamonds in Alberta will continue for the foreseeable future.

Saskatchewan. Following the 1989 confirmation of seven kimberlite pipes in the Fort à la Corne area (figure 2 [19]), joint-venture partners Uranerz and Cameco drilled 12 additional kimberlites by 1991 (Lehnert-Thiel et al., 1992). In 1992, after De Beers joined the joint venture, a major drilling program resulted in the confirmation of 20 new kimberlites in 1992-93 and established that a high percentage were diamondiferous. The addition of Kensington Resources to the joint venture in 1995 led to further drilling, and the identification of an additional 31 kimberlites by 1997 (69 of the original 71 geophysical targets outlined in 1989 proved to be kimberlites). Four additional kimberlites have been found by other companies. The pipes range from 2.7 to 184 ha and contain from 3 to 675 million tonnes of kimberlite; some are extraordinarily large by world standards (Robertson, 2002g).

Diamonds have been recovered from more than half of the Fort à la Corne kimberlites, and close to

Figure 17. These rough diamonds were selected from $a$ $12.54 \mathrm{ct}$ parcel recovered from a 22.8 tonne bulk sample at the K252 pipe in the Buffalo Hills, Alberta. The largest stone in the upper left is $2.9 \mathrm{~mm}$ long. Courtesy of Ashton Mining of Canada.

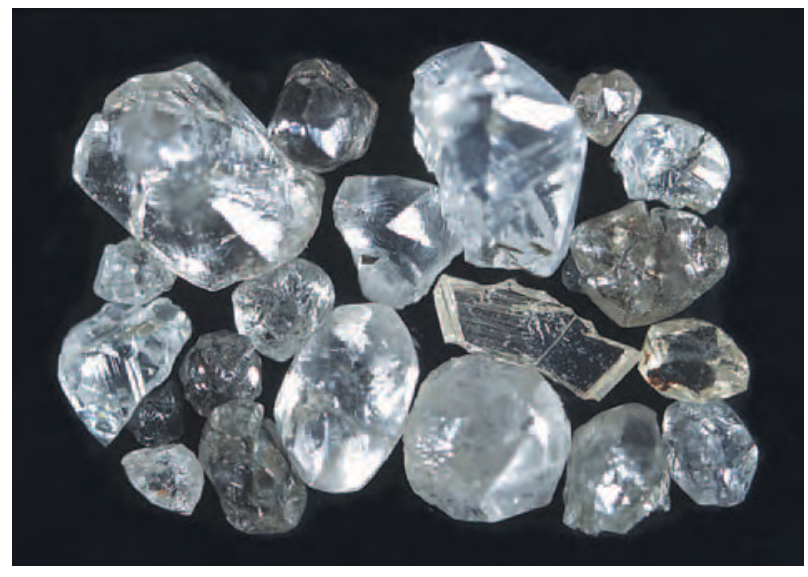

$70 \%$ of them are gem quality (Jellicoe et al., 1998). Exploration and modeled grades range from $<0.01$ to about $0.3 \mathrm{ct} /$ tonne. A significant problem hindering evaluation of the Fort à la Corne kimberlites is that they are overlain by up to $100 \mathrm{~m}$ of glacial till and unconsolidated sediments, which makes it more difficult and expensive to obtain the appropriate large samples.

In 2000, De Beers carried out an in-depth resource evaluation at Fort à la Corne, which was followed by a mini-bulk sampling program on two high-priority bodies (141 and 122). A larger minibulk sample was taken from body 141 in 2001, with an exploration grade of $\sim 0.05 \mathrm{ct} /$ tonne, modeled grade of $0.08-0.19 \mathrm{ct} /$ tonne, and modeled stone value of $\$ 148 /$ ct (www.kensington-resources.com; Robertson, 2002g; Janse, 2002). Also in early 2000, Shore Gold started an extensive core drill program at its diamondiferous Star kimberlite. Recent minibulk sample results are similar to those for body 141 (www.shoregold.com) and have led to plans for bulk sampling. Like 141, the Star kimberlite is extremely large (estimated $>500$ million tonnes).

Ontario. For most of the 1990s, events in the NWT eclipsed diamond activities in Ontario. Nevertheless, in 1995, microdiamonds were found in a mafic dike exposed in a road cut along the Trans Canada Highway, $35 \mathrm{~km}$ north of Wawa (figure 2 [25]; Thomas and Gleason, 2000). Subsequent work by several small companies (e.g., Spider Resources) located additional dikes over a wider area. The diamonds, although abundant in places, are small, with the largest found $0.1 \mathrm{ct}$ (Janse, 2001). As exploration activity increased in 2000-02, an extensive area of Archean diamond-bearing volcanic rocks was discovered in the immediate region of the mafic dikes. These unusual volcanic rocks are currently being sampled by exploration companies Pele Mountain Resources and Band-Ore, with assistance from De Beers and Rio Tinto, respectively, to determine their economic potential (Robertson, 2002c).

Elsewhere in Ontario, five diamond-bearing kimberlites have been found in the Kyle Lake area of the James Bay Lowland (Janse, 1995b; figure 2 [23]), but the one with the best grade is too deeply buried to be considered economic at this time. In the adjacent Attawapiskat kimberlite field (figure 2 [24]), evaluation of the Victor kimberlite began in 1998. The Victor kimberlite comprises two pipes that coalesce at the present surface with an area of $\sim 15$ ha. With a quoted ore value of $\$ 94 /$ tonne (Robertson, 
2002f), Victor has the potential to host Canada's first diamond mine outside the NWT (table 4). However, it is in a remote area, the grade is highly variable, and the geology is complex (Wood, 2002).

Quebec. Several ultrabasic dikes (up to $3 \mathrm{~m}$ wide) were discovered in 1991 outcropping on cliff faces in the Torngat region of northern Quebec (figure 2 [32]). In 1999, Twin Mining determined that three of the dikes contained diamonds. Subsequent exploration found another set of dikes about $10 \mathrm{~km}$ to the southwest (Moorhead et al., 2000). Some can be traced for $\sim 37 \mathrm{~km}$ (Janse, 2002). At present little work is being done in the area and the dikes are considered uneconomic. However, at least 50 companies are currently exploring in Quebec. By mid2002, seven diamond-bearing kimberlites had been found by partners Ashton Mining and SOQUEM in the Otish Mountains (figure 2 [30]), thus defining a new kimberlite field (Robertson, 2002d). A diamondiferous kimberlite dike was found in early 2002 by Majescor Resources at Wemindii, in the Quebec side of the James Bay Lowland (figure 2 [31]).

Other Jurisdictions. Since 1990, limited diamond exploration has been conducted in British Columbia, the Yukon Territory, Labrador, and Manitoba (see, e.g., Natural Resources Canada, 2000), but with no success to date. Nevertheless, in the entire country only the three Maritime provinces (Nova Scotia, New Brunswick, and Prince Edward Island) did not have any diamond exploration activity.

\section{ECONOMIC ATTRIBUTES OF CANADIAN DIAMOND DEPOSITS}

Diamond Exploration and Infrastructure. Diamond exploration in Canada has been ongoing for four decades, and in recent years virtually all major diamond exploration companies have had a significant presence there. For example, in 2001 De Beers spent $40 \%$ of its $\$ 73$ million global exploration budget in Canada (Robertson, 2002f), whereas BHP Billiton spends $25 \%$ of its total exploration budget on diamonds, most of which is in Canada (Janse, 2002). As of the end of September 2002, 538 kimberlites had been discovered (table 3), about $90 \%$ in the last decade. More than half of the Canadian kimberlites are diamondiferous, which far exceeds the world average of about $20 \%$ (A. J. A. Janse, pers. comm., 2002). Historically, only about $1 \%$ (i.e., about 50 ) of the world's kimberlites have been economic. In
Canada, however, the percentage is significantly higher, especially in Lac de Gras where $12(\sim 5 \%)$ of the 247 kimberlites are economic.

During the 1990s, approximately Can $\$ 900$ million was spent on diamond exploration and deposit evaluation in Canada (Natural Resources Canada, 2000, 2002), and more than twice that amount on the construction of the Ekati and Diavik mines. Exploration reached its peak in 1994-96, when about 150 companies were involved and about $200,000 \mathrm{~km}^{2}$ in the Lac de Gras area were staked (Duval et al., 1996). During this period, an average of Can\$146 million was spent annually for diamond exploration, with $88 \%$ of that spent in the NWT. By 1997-99, only about 50 exploration companies were active in Canada, with expenditures down to an average of Can $\$ 113$ million annually. Of this, $79 \%$ was spent in the NWT, but Alberta and Ontario received relatively more exploration attention. Preliminary data for 2000 and 2001 indicate that an average of Can $\$ 98$ million was spent annually on diamond exploration, of which $67 \%$ was spent in NWT and Nunavut, with significant increases in Ontario and Quebec relative to the rest of the country (Natural Resources Canada, 2000, 2002).

Economic Parameters of the Lac de Gras Kimberlites in a Worldwide Context. The small size of most of the Lac de Gras kimberlite pipes, as compared to economic diamond mines elsewhere in the world, is evident from figure 18. Eight of nine Lac de Gras kimberlites (selected from the Ekati and Diavik mine plans) are 5 ha or less, significantly smaller than active diamond mines elsewhere, which are all $>10$ ha in size. However, five of these nine Lac de Gras kimberlites (Misery and four Diavik pipes) have exceptional diamond ore grades (3.0-5.2 ct/tonne; Kjarsgaard et al., 2002) as compared to other active diamond mines (figure 19). The only kimberlite that had a higher grade (variably reported as $6 \mathrm{ct} /$ tonne by Janse, 1993, and 11 ct/tonne by Duval et al., 1996) is the mined-out Internationalaya pipe in Russia.

There is a wide variation in the average stone value (quality) for the individual Lac de Gras kimberlite pipes. Ekati's currently mined Panda pipe has an average stone value of $\sim \$ 170$ per carat (table 2). From exploration parcels, BHP Billiton has reported average exploration stone values of $>\$ 100$ per carat for the Koala and Fox pipes, which are clearly in the upper echelon of stone values from active worldwide mines (figure 20). It is because of the combination of very high grades coupled with 


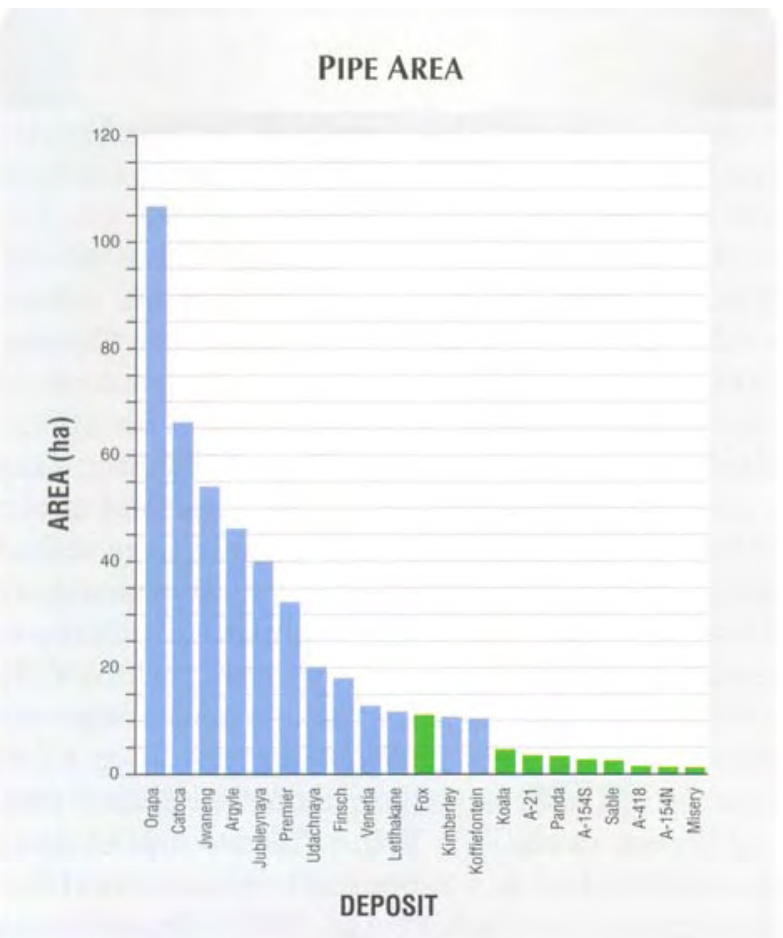

Figure 18. In general, the surface area of kimberlite pipes in Canada's Lac de Gras area (green) is much smaller than that of the other pipes worldwide that are being mined actively (blue). Data sources: EkatiJ. A. Carlson (pers. comm., 2002); Diavik-Graham et al. (1999); Udachnaya, Jubileynaya, and ArgyleJanse (1993); southern African-Janse (1996).

high stone value that the Panda pipe has a mine ore value of $>\$ 150 /$ tonne (figure 21 ), higher than the Jwaneng (\$138/tonne) and Udachnaya (\$112/tonne) kimberlites. Further, the exploration ore value for the A-154S and A-418 kimberlites also exceeds $\$ 150 /$ tonne. In summary, the Lac de Gras pipes tend to be smaller, low-tonnage bodies that may have exceptionally high diamond grades, coupled with quite variable (moderate to high) stone values. Thus far, development of the Ekati and Diavik mines in the Lac de Gras field has been economically viable only because each encompasses multiple small pipes that are close together and provide sufficient tonnage for a 15-20 year mine life.

Contribution of Canadian Rough Diamonds to World Supply. From 1999 (the first year of full production at the Ekati mine) to 2001, total world annual production increased from $~ 110$ Mct in both 1999 and 2000, to 119 Mct in 2001. This production was valued at $\$ 7.2$ billion in 1999 and $~ \$ 7.9$ billion in both 2000 and 2001 (Rombouts, 2000,

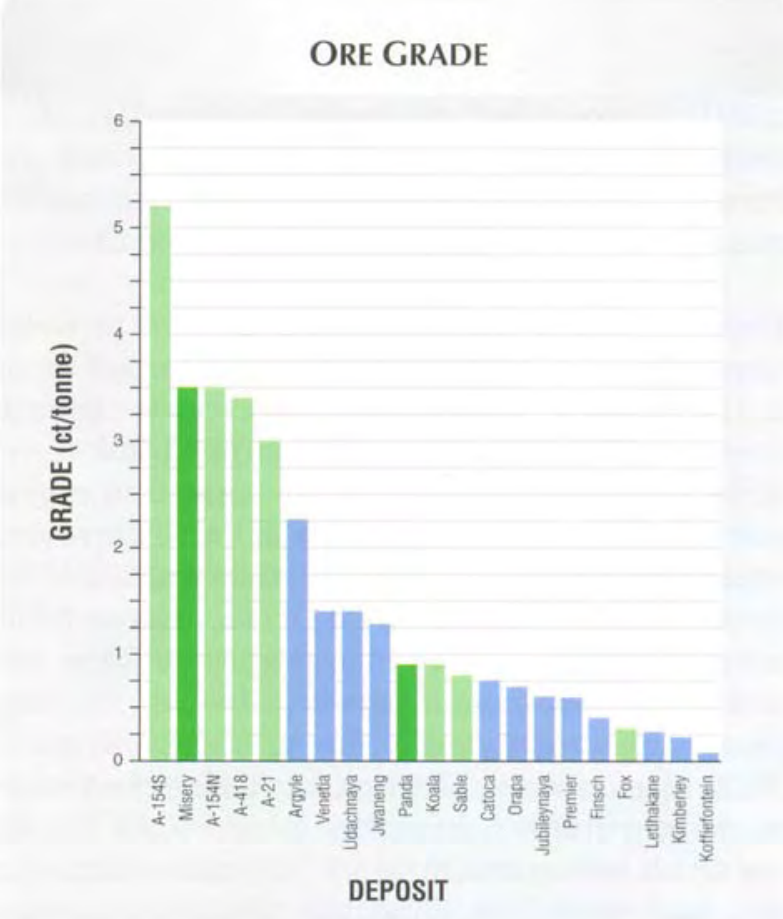

Figure 19. Relative to other worldwide kimberlites being mined actively (blue), many of the Lac de Gras kimberlites (green) have high diamond ore grades. The ore grade for Panda and Misery is shown in dark green, because they are being mined actively. Other Canadian pipes are shown in light green, since their data are based on exploration grade. Data sources: Ekati_Kjarsgaard et al. (2002); Diavikwww.diavik.ca; Udachnaya, Jubileynaya, Catoca, and Argyle-Rombouts, (2002); others-De Beers Consolidated Mines (2001).

2001, 2002). Thus, the average value per carat of world production varied between $\$ 71 / \mathrm{ct}$ and $\$ 66 / \mathrm{ct}$ in the period 1999-2001. The 2.4 Mct produced from Ekati's Panda pipe in 1999 and 2000, at $\sim 170 / \mathrm{ct}$, had an annual total value of $\sim 415$ million (table 2). This was about $2 \%$ by weight and $5 \%$ by value of world production.

The Panda pipe, however, is approaching the end of its open-pit mine life, so the Ekati mine will soon draw ore from several kimberlite pipes with different grades and values per carat. The production numbers will change as these new pipes are brought on stream. In 2001, a larger number of carats ( 3.7 Mct) was produced from Ekati with a lower value per carat ( $\$ 144)$ compared to the two previous years. This was caused by drawing ore not only from the Panda pipe, but also from the Misery pipe, which, according to BHP's 2000 Annual Report, has a higher diamond grade ( $3.3 \mathrm{ct} /$ tonne, only stones $>1.5 \mathrm{~mm}$ ) but a lower 


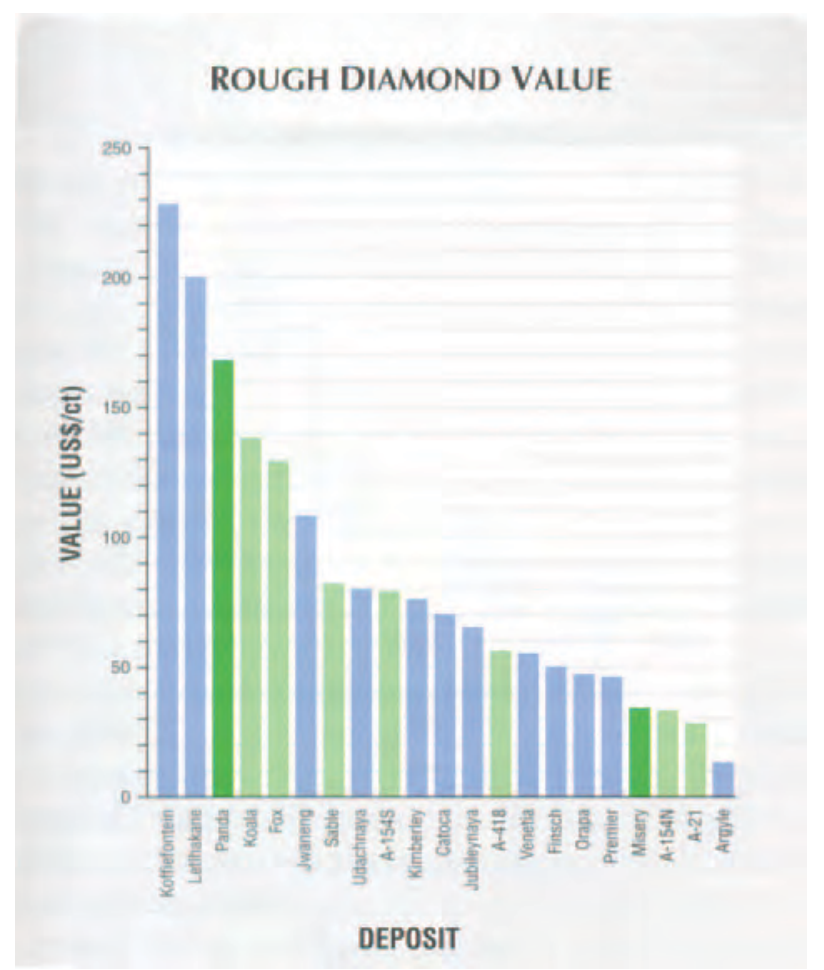

Figure 20. A wide variation in average rough diamond value is shown for the Lac de Gras kimberlites. Colors as in figure 19, and data sources as per figure 18.

value per carat (\$34). Production of rough in 2002 is expected to reach $\sim 4$ Mct due to a greater contribution of ore from the higher-grade Misery pipe (Kjarsgaard et al., 2002).

When the Diavik mine reaches full production, by late 2003 or early 2004, about 6 Mct per year will be added to world production at an average value of $\sim$ \$63/ct (Kjarsgaard et al., 2002). In the first 10 years of production, Diavik is expected to produce about $\$ 475$ million annually, because of the relatively high value $(\$ 79 / \mathrm{ct}$ ) of the diamonds from the A-154 South pipe. This is expected to drop to $<\$ 375$ million per year when production is primarily from the other three pipes. Primary diamond deposits (such as the A-154 South kimberlite) that produce such large amounts of diamonds are rare. Currently only six such mines worldwide produce more than 3 Mct per year: Argyle (Australia), Orapa and Jwaneng (Botswana), Udachnaya and Jubileynaya (Russia), and Venetia (South Africa).

By the end of this decade, new production may also be coming from at least one of the several advanced projects listed in table 4. Moreover, the original (1997) Ekati mine plan anticipated that the current daily processing of 9,000 tonnes of ore would be doubled to 18,000 tonnes beginning in 2008

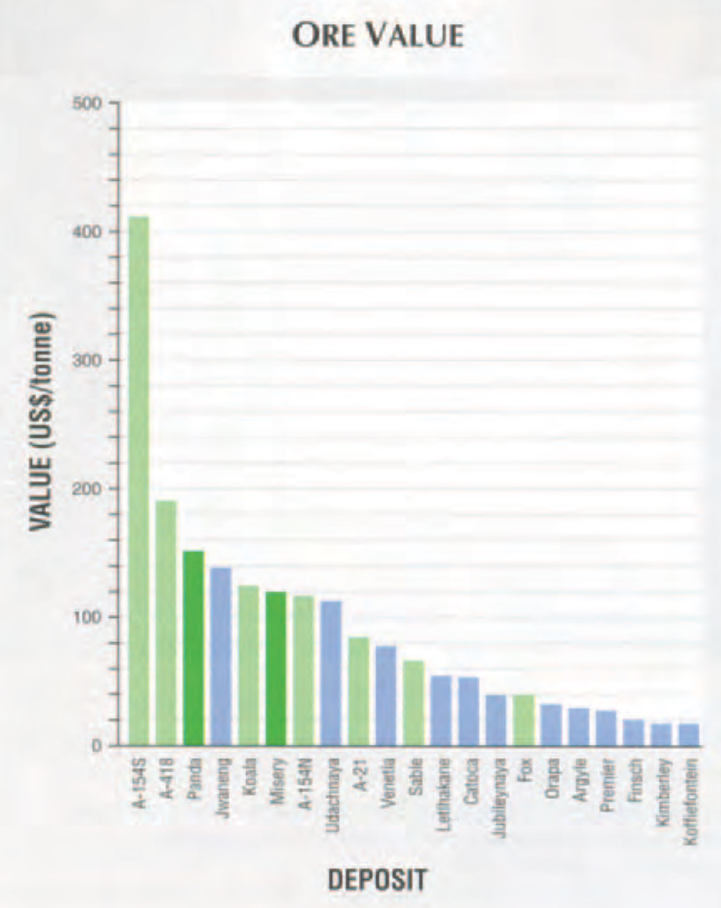

Figure 21. Some of the Lac de Gras kimberlites are inferred to have higher ore values (determined by diamond grade multiplied by average diamond value) than other active worldwide diamond mines. Colors as in figure 19, and data sources as per figure 18.

(Johnson and Koivula, 1998; Kjarsgaard et al., 2002).

Table 5 lists the contribution of the world's eight most important countries to rough diamond production by weight and value for 2001 (Rombouts, 2002). In 2001, Canada was the world's seventh rough diamond producer by weight and fifth by value. By the end of 2003 (or at least in 2004), Canada's annual production from two mines (Ekati and Diavik) is expected to be $\sim 10$ Mct valued at $\sim \$ 1$ billion, thus elevating Canada to the world's sixth most important rough diamond producer by weight and fourth by value $(8 \%$ and $10 \%$, respectively), just slightly behind South Africa in both categories.

\section{SELLING, CUTTING, AND BRANDING OF CANADIAN DIAMONDS}

Sales. In May 1998, BHP (now BHP Billiton) Diamonds Inc. was appointed sales representative for the Ekati mine for five years. Sales commenced in January 1999 through the BHP Diamonds Inc. sales office in Antwerp, Belgium. A sorting and valuation facility, located near the Yellowknife airport, opened in February 1999. The facilities are used for cleaning, 
TABLE 5. Production of rough diamonds by weight and value worldwide in 2001 . $^{\text {a }}$

\begin{tabular}{lrrr}
\hline Country & Carats & $\begin{array}{r}\text { Value of produc- } \\
\text { tion (US } \$ \text { ) }\end{array}$ & $\begin{array}{r}\text { Unit value } \\
\text { (US } \$ \text { /ct) }\end{array}$ \\
\hline Botswana & $26,416,000$ & $2,193,870,000$ & 83 \\
Australia & $26,070,000$ & $293,700,000$ & 11 \\
Russia & $20,500,000$ & $1,650,000,000$ & 80 \\
Democratic Republic & $19,637,000$ & $496,310,000$ & 25 \\
of Congo & & & \\
South Africa & $11,301,000$ & $1,144,655,000$ & 101 \\
Angola & $5,871,000$ & $803,145,000$ & 137 \\
Canada & $\mathbf{3 , 6 8 5 , 0 0 0}$ & $\mathbf{5 3 0 , 6 4 0 , 0 0 0}$ & $\mathbf{1 4 4}$ \\
Namibia & $1,502,000$ & $322,340,000$ & 215 \\
All others & $3,749,000$ & $450,400,000$ & 120 \\
World total & $118,731,000$ & $7,885,060,000$ & $\mathbf{6 6}$
\end{tabular}

a From Rombouts (2002).

${ }^{b}$ Value of production for Canada differs slightly from that presented

in table 2 because of variations in the factor used to convert

Canadian to U.S. dollars.

sizing, and basic sorting of the rough diamonds, as well as for the division of product for various marketing channels, government valuation, and sales to NWT manufacturers. Rough diamonds from the Ekati mine are valued before export so that royalties $(14 \%$ of the price received for the diamonds minus permitted expenses) can be estimated and paid to the federal government when the diamonds are sold.

The current marketing program for Ekati diamonds involves sales through three separate channels. Approximately $10 \%$ by value, in specific sizes and qualities, is sold to three cutting and polishing factories operating in the NWT. Based on a three-year agreement that became effective in January 2000, $35 \%$ of the run-of-mine production has been sold to the De Beers Diamond Trading Company (formerly Central Selling Organisation). The remaining 55\% is sold through the Antwerp office to international manufacturers and traders. Currently, most of the sales from the Antwerp office are made in broad assortments to a limited number of regular customers on a five-week cycle. Remaining sales are made in smaller, more specific assortments to dealers and manufacturers on a nonregular basis.

In September 2002, BHP Billiton announced that it would not renew the marketing arrangement with De Beers after the final 2002 shipment of rough diamonds. BHP Billiton will now sell $90 \%$ of its production to international manufacturers and traders through its Antwerp office. It will use the share previously sold to De Beers to pursue value-added opportunities.

Diamonds from the Diavik mine will be sorted and valued in a separate facility at Yellowknife, and will follow different routes to the cutting centers. After the production is divided in Yellowknife, Rio Tinto's portion (60\% of the total) will be sold through a facility in Antwerp, whereas Aber's portion $(40 \%)$ will be sold out of a rough diamond sorting facility in Toronto. Most significant is that Aber has a marketing arrangement with Tiffany \& Co. (which also, at $14.9 \%$, is Aber's largest shareholder), whereby Aber will supply Tiffany with a minimum of $\$ 50$ million of rough diamonds in certain specific categories for a 10-year period. The remainder of Aber's share of the Diavik production (possibly up to $\$ 170$ million) will go to an Antwerp-based marketing joint venture between Aber and Antwerp diamantaire and manufacturer Overseas Diamonds N.V., for placement in the diamond markets and cutting centers. However, entry into jewelry manufacturing at a later date is not excluded (Aber Diamond Corp., 2002).

Cutting Diamonds in the NWT. The Government of the Northwest Territories (GNWT), the aboriginal people, and the federal government of Canada are committed not only to developing diamond mines with due regard to the environment and indigenous cultures, but also to adding value to the diamonds within Canada (Paget, 1999). These value-added opportunities include cutting and polishing, jewelry manufacturing, and tourist-related activities ("Diamond Facts 2000/01," 2001), which have been initiated primarily by the GNWT. Although BHP Billiton has agreed to provide up to $10 \%$ by value of Ekati's production to three NWT manufacturers (Paget, 1999), currently only a 7\% allocation is used (Janse, 2002). Based on a "memorandum of understanding" between the GNWT and Diavik Diamond Mines, a supply of rough diamonds from forthcoming Diavik production also will be manufactured in the NWT ("Diamond Facts 2000/01," 2001). An in-depth review of the NWT cutting and polishing industry can be found in Smillie (2002).

One cutting and polishing facility (Sirius Diamonds Ltd.; figure 22) opened in 1999, and two others (Deton'Cho Diamonds Inc. and Arslanian Cutting Works NWT Ltd.) opened in 2000. Manufacturers are attracted to Yellowknife by the very generous financial and other incentives offered by the government to companies that create jobs there (for details, see Even-Zohar, 2001; Smillie, 
2002). By world standards these cutting facilities are small, currently employing a total of 60-80 people. They specialize in producing faceted diamonds from 30 points to 1 carat (see, e.g., figure 23). In view of the high labor and related manufacturing costs in Canada relative to most other cutting centers, the diamond rough given to the Yellowknife factories is typically of a higher quality. It has been projected that, in five years, 200 cutters in these three factories will process some 5,000 carats of rough per month (Even-Zohar, 2001). Tiffany is currently constructing a manufacturing facility in Yellowknife, where it intends to cut one-quarter of its share of diamonds from the Diavik mine (Robinson, 2002). Diamonds mined in Canada are popular, and premiums of up to 20\% have been reported (Even-Zohar, 2001). This has led to the serious suggestion (Waytiuk, 2001) that retailers add to the established "4 $\mathrm{Cs}^{\text {" a fifth }}$ "C" - "Canadian."

Branding Canadian Diamonds. Although Argyle marketed "Champagne" and "Cognac" diamonds in the early 1990s, and some manufacturers considered branding as an option to offset shrinking profits in the mid-1990s (Scriven, 1997), the branding of diamonds did not become a significant marketing tool until the late 1990s. By that time, though, many diamond brands had been introduced, frequently with price premiums of up to $15 \%$. Drucker (2000) lists 22 different brands, many with laser-inscribed girdles and/or certificates, almost all of which are based on specific cuts or shapes. Under a pilot program that started in 1999, De Beers provided loose branded "De Beers" diamonds to a retail chain in England (Sielaff, 1999). Brand naming an otherwise generic product, such as diamond, is a proven way of enticing customers, as evidenced by the success of other luxury goods such as watches and clothing (Scriven, 1997). The brand name implies quality, distinctiveness, prestige, and confidence.

Canadian diamonds are unique in that they are the only diamonds that are branded on the basis of origin. Because of the "conflict diamond" issue in recent years, origin has become an important consideration. In 1999, Sirius Diamonds became the first to market diamonds as being mined and cut in Canada. Their "branded" diamonds are laserinscribed with a polar bear and a serial number, and come with a certificate. Soon other brands, identified with a snowflake, maple leaf, beaver, or other logos representative of Canada, entered the market (see, e.g., figure 24).

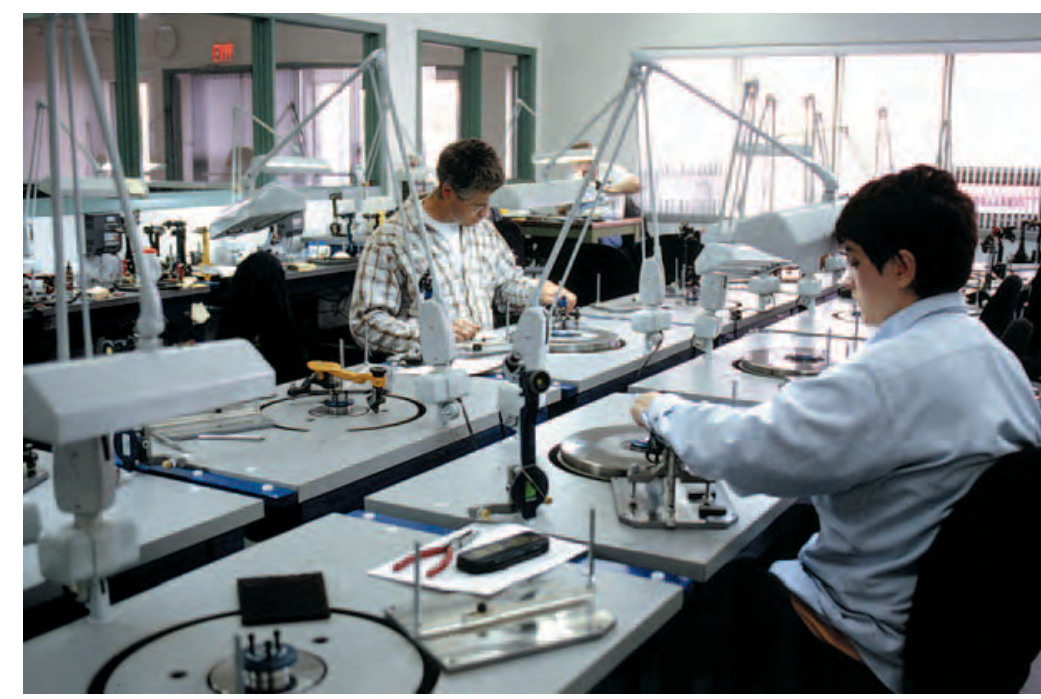

Figure 22. These diamond polishers are working at Sirius Diamonds in Yellowknife, NWT. Sirius was the first cutting facility to open in Canada's Far North, to manufacture diamonds from the Ekati mine. Photo () Tim Atherton, 2000.

The Government of the NWT introduced a program to certify branded diamonds as being mined, cut, and polished in the Northwest Territories. The program, the only one of its kind in the world, has a strict monitoring system that follows the diamond from

Figure 23. The diamond-cutting factories in Yellowknife typically produce diamonds ranging from 30 points to one carat. The stones shown here were fashioned by Sirius Diamonds; photo (C) Roy Tanami/Ursus.

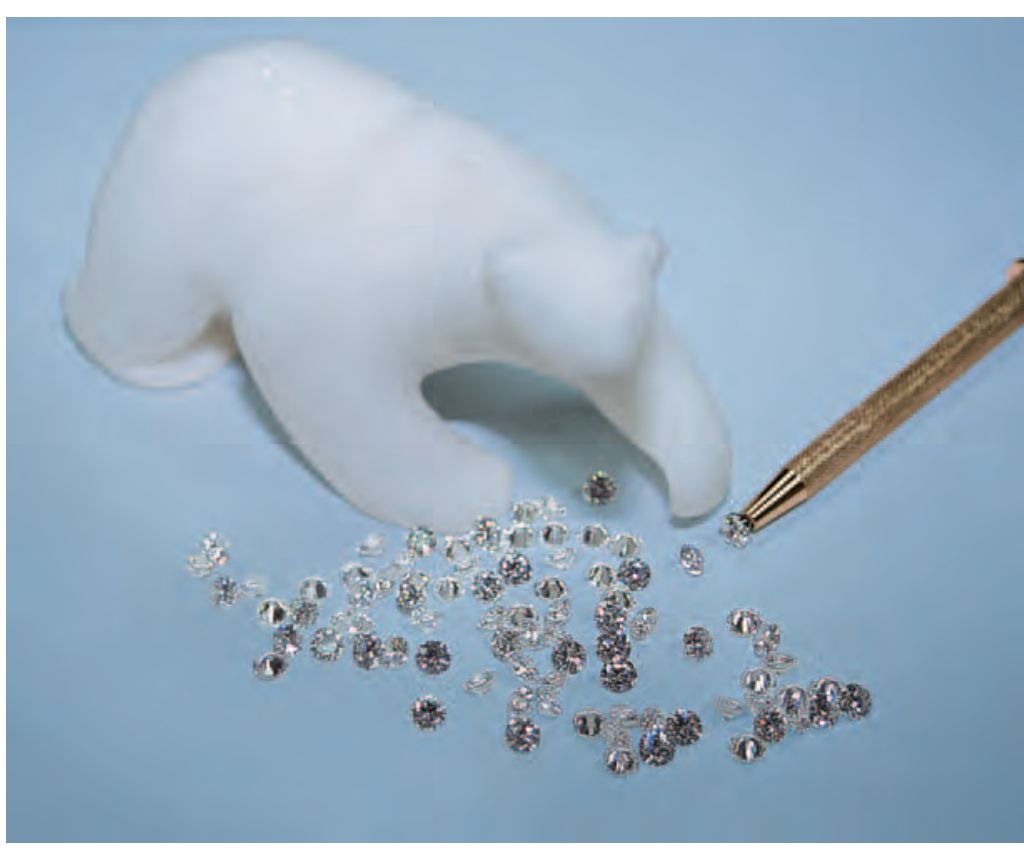


mine to factory (in Yellowknife). Since November 2000, Canadian Arctic ${ }^{\mathrm{TM}}$ diamonds have come with a certificate signed by the Premier of the NWT attesting to their authenticity ("Diamond Facts 2000/01," 2001). Other examples of NWT-branded diamonds include the Loon ${ }^{\mathrm{TM}}$ diamond in Canada, and the Tundra $^{\mathrm{TM}}$ and Canadia ${ }^{\mathrm{TM}}$ diamonds in the U.S.

\section{EFFECTS OF CANADIAN GOODS ON THE DIAMOND PIPELINE}

Since it was established in 1935, the De Beers Central Selling Organisation (CSO) has played a key role in maintaining stability in the diamond market through the allocation of rough diamonds to the cutting centers (i.e., the single-channel marketing system). For most of this period, there were relatively few major producers, and they were amenable to selling their rough diamonds through the CSO. However, the influx of rough diamonds from various sources over the period 1991-96, and the marketing of Argyle (Australia) diamonds independently from De Beers starting in 1996, has put a severe strain on the De Beers pipeline (Sevdermish et al., 1998). In July 2000, De Beers formally announced that it would end its efforts to control world diamond supply (see, e.g., Boyajian, 2000). Nicholas Oppenheimer (2002, p. 30) subsequently acknowledged that the Canadian diamond discoveries contributed to this monumental decision: "As new sources of supply opened up-particularly in Canada-it became evident that that role could not be sustained." In 2001, De Beers's share of the rough diamond market slipped to $57 \%$ from its historical $\sim 80 \%$ (Even-Zohar, 2002).

With De Beers's changed role, all rough diamond producers are now competing for market share. Strategies are being developed to cope with the new competition. The one preferred by current and prospective Canadian producers is vertical integration (a supply chain) from the mine to the retail consumer, that is, a Canadian pipeline. Even-Zohar (1999, p. 35) predicted, "Ultimately, competitive dominance will only be achieved by an entire supply chain. Competition battles will be fought supply chain against supply chain."

Ekati has a multi-faceted approach to its distinctive pipeline. Not only does it sell to the manufacturers mentioned above, but it also sells a small percentage as branded and certified "Made in Canada" diamonds, laser-inscribed with a maple leaf logo, through a limited number of primarily Canadian retailers (polishing is done by contract manufacturers). BHP Billiton, the majority owner of the mine, also sells polished ("Aurias") diamonds over the Internet ("Ekati to 'brand' its diamonds," 2001).

\section{CONCLUSIONS}

The first 60 years after Hobbs (1899) suggested the likelihood that diamonds would be found in Ontario saw no organized diamond exploration, in part because of the logistical difficulties of working in those parts of the Canadian sub-Arctic and Arctic that contained the most favorable geologic terrain. Exploration formally started in 1960, and activity expanded through the 1980s into extremely remote areas. Starting in the 1980s, new scientific concepts, mainly those involving airborne geophysical surveys, glacial geology, and the use of indicator minerals, were incorporated into many of the exploration programs.

Figure 24. Unlike most other diamonds, Canadian diamonds are typically branded to show their country of origin. Many organizations brand their Canadian diamonds by inscribing logos such as the polar bear (Sirius Diamonds) on the left, or a maple leaf and the name of the retailer (center, Henry Birks 4 Sons), or the name of the mine (far right), usually in combination with a registration number. Photomicrographs by Mitchell Moore; magnified (left to right) $55 \times, 30 \times$, and $50 \times$.
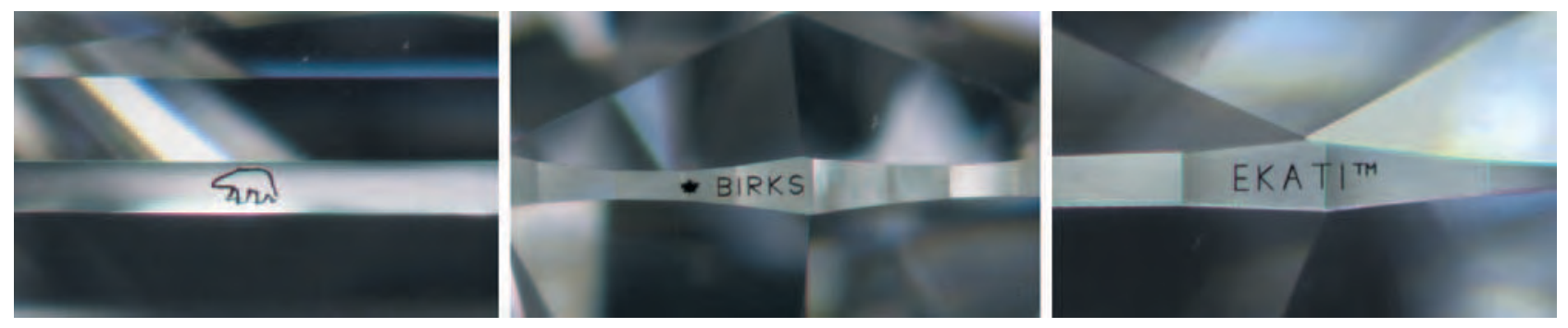


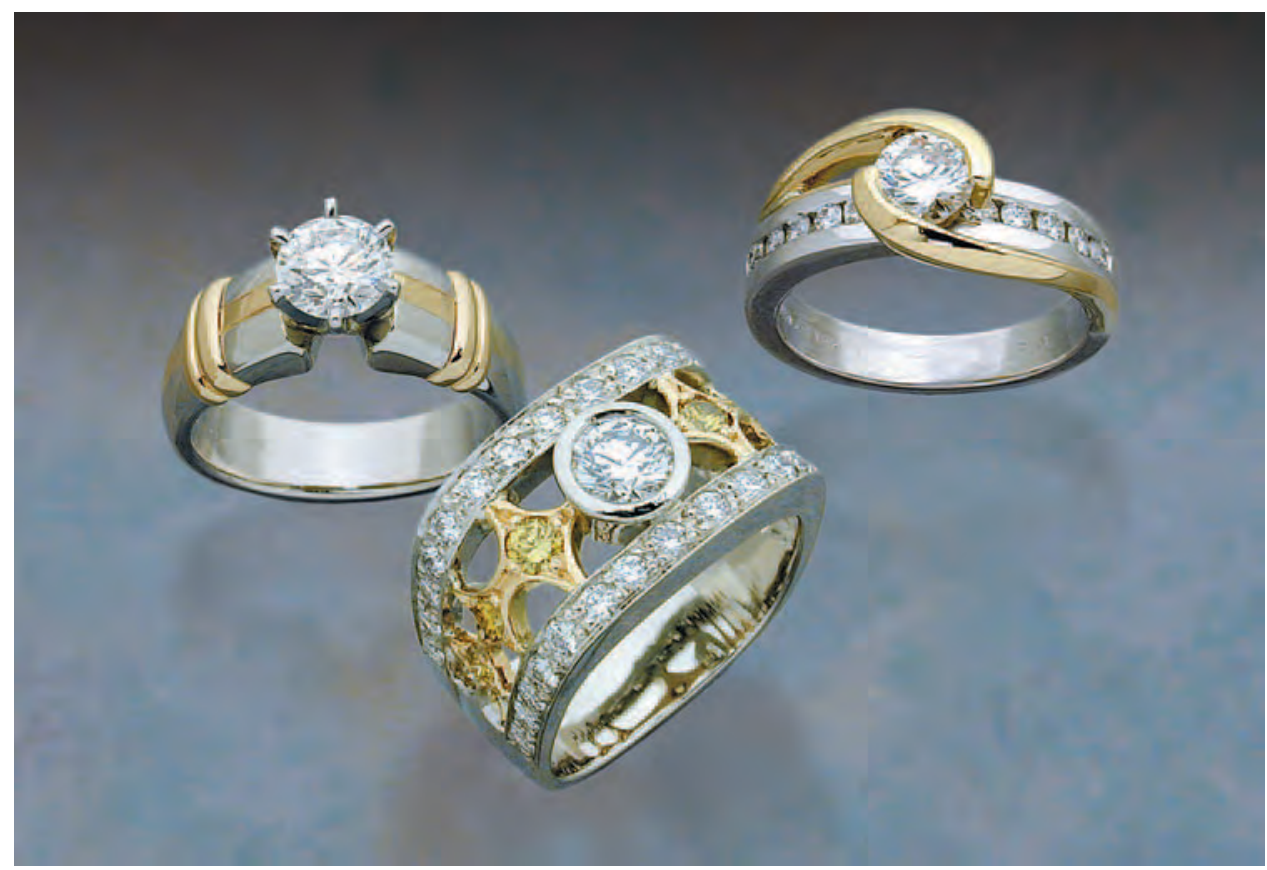

Figure 25. Canadian diamonds are now being featured by jewelry designers and retailers. The center diamonds in these three rings have all been inscribed with the Sirius polar bear logo. The center diamonds are, from left to right, $0.81,0.42$, and $0.51 \mathrm{ct}$; all are set in $18 \mathrm{~K}$ yellow and white gold or (far right) platinum. Photo (C) 2002 Peter Kangas Jewellers Ltd.

The breakthrough came in 1991, when diamondbearing kimberlite was discovered at "Point lake." Since this discovery, Canada has become a focal point for much of the world's diamond exploration. Geologists have benefited from significant advances in technological methods, with the result that 538 kimberlites, over half of which are diamondiferous, are now known throughout the country; 90\% have been discovered in the last decade. New discoveries continue to be announced, albeit at a slower rate than in recent years.

Canada's first diamond mine, Ekati, began production in late 1998. After Canada's second mine, Diavik, reaches full production (possibly in late 2003), annual rough diamond production from the two mines will be $\sim 10$ Mct valued at $\sim \$ 1$ billion. This will rank Canada as the sixth most important producer in the world by weight and fourth by value. It appears likely that additional mines (e.g., Snap Lake, Gahcho Kué) will be in production by the end of this decade (barring unforeseen economic or other events). Canada has added a new level of competition to other segments of the diamond business, ranging from the cutting and polishing of higher-value stones, to branding, to the retailing of "Canadian diamonds" in fine jewelry (figure 25). As these aspects of the Canadian diamond industry continue to evolve, Canada will play an increasingly important role in the world diamond market.

\section{ABOUT THE AUTHORS}

Dr. Kjarsgaard (bkjarsga@nrcan.gc.ca) is a research scientist with the Geological Survey of Canada, Ottawa, and Dr. Levinson is professor emeritus in the Department of Geology and Geophysics, University of Calgary.

ACKNOWLEDGMENTS: The authors thank the following for their comments: Dr. A. J. A. "Bram" Janse (Archon Exploration Pty. Ltd., Carine, Western Australia), Dr. J. E. Shigley (GIA Research, Carlsbad), R. Shor (GIA, Carlsbad), Dr. M. L. Manson (Aber Diamond Corp., Toronto), Dr. L. H. Thorleifson (Geological Survey of Canada, Ottawa), and two anonymous reviewers. For helpful comments on the text and for supplying photographs, the authors also thank J. A. Carlson (Kelowna, British Columbia) and Denise Burlingame (Yellowknife) of BHP Billiton; Don
Boucher (Sudbury, Ontario), Bruce Wyatt and Linda Dorrington of De Beers Canada (Toronto); R. Hopkins and E. Thomas of Navigator Exploration (Nancouver); M. Irving and C. Malmsten (Government of the Northwest Territories, Yellowknife); Prof. $R$. E. Folinsbee (University of Alberta, Edmonton); P. R. Maki-Scott (Saskatchewan Research Council, Saskatoon); R. T. Boyd and Dr. T. E. McCandless (Ashton Mining of Canada, North Vancouver); and Prof. A. E. Oldershaw (University of Calgary). J. A. Armstrong (DIAND, Yellowknife), M. Tremblay (consultant), B. Hudson (Alberta Energy, Edmonton, Alberta), S. Caroline Glasbey (Aber Diamond Corp.), and T. Hoeffer (Diavik Diamond Mines, Yellowknife) all provided useful information. C. Langford (Canadian Diamonds magazine, Yellowknife) and P. Kangas (Peter Kangas Jewellers Ltd., Calgary, Alberta) also helped with photos. This is GSC publication Number 2002151. 


\section{REFERENCES}

Aber Diamond Corp. (2002) 2001/2002 Annual Report. Toronto, Ontario.

Beardmore-Gray T. (1999) De Beers plays its part in the Canadian diamond dream. In-Sight, Spring 1999, pp. 3-7.

Bell R. (1906) The occurrence of diamonds in the drift of some northern states. Journal of the Canadian Mining Institute, Vol. 9, pp. 124-127.

Blackadar R.G., Christie R.L. (1963) Geological Reconnaissance, Boothia Peninsula, and Somerset, King William, and Prince of Wales Islands, District of Franklin. Geological Survey of Canada, Paper 63-19.

Blatchley W.S. (1903) Gold and diamonds in Indiana. Indiana Department of Geology and Natural Resources 27th Annual Report (1902), pp. 11-47.

Blue A. (1900) Are there diamonds in Ontario? Ontario Bureau of Mines, Annual Report, No. 9, pp. 119-124.

Boyajian W.E. (2000) Gem News: De Beers's newly stated direction. Gems «) Gemology, Vol. 36, No. 3, p. 261.

Boyd W. (1998) Canadian diamond mining \& exploration-The new billion dollar industry. Canadian Gemmologist, Vol. 19, No. 2, pp. 42-54.

Brown D.D., Bennett G., George P.T. (1967) The Source of Alluvial Kimberlite Indicator Minerals in the James Bay Lowland. Ontario Department of Mines, Miscellaneous Paper 7.

Brummer J.J. (1978) Diamonds in Canada. Canadian Institute of Mining and Metallurgy Bulletin, Vol. 71, No. 798, pp. 64-79.

Brummer J.J. (1984) Diamonds in Canada. In G.R. Guillet and W. Martin, Eds., The Geology of Industrial Minerals in Canada, Special Volume 29, Canadian Institute of Mining and Metallurgy, Montreal, pp. 311-320.

Brummer J.J., MacFadyen D.A., Pegg C.C. (1992a) Discovery of kimberlites in the Kirkland Lake area northern Ontario, Canada. Part I: Early surveys and the surficial geology. Exploration and Mining Geology, Vol. 1, No. 4, pp. 339-350.

Brummer J.J., MacFadyen D.A., Pegg C.C. (1992b) Discovery of kimberlites in the Kirkland Lake area Northern Ontario, Canada. Part II: Kimberlite discoveries, sampling, diamond content, ages and emplacement. Exploration and Mining Geology, Vol. 1, No. 4, pp. 351-370.

Burgess J. (2001) The Diavik Diamonds Project-An update. Industrial Minerals in Canada, Program and Extended Abstracts for the 37th Forum on Geology of Industrial Minerals, Victoria, British Columbia, May 22-25, pp. 115-119.

Carlson J.A., Kirkley M.B., Ashley R.M., Moore R.O., Kolebaba M.R. (1995) Geology and exploration of kimberlites on the BHP/Dia Met claims, Lac de Gras region, Northwest Territories, Canada. In N.V. Sobolev, Chairman, Extended Abstracts, Sixth International Kimberlite Conference, Novosibirsk, 1995, United Institute of Geology, Geophysics and Mineralogy, Siberian Branch of Russian Academy of Sciences, Novosibirsk, pp. $98-100$.

Carlson J.A., Kirkley M.B., Thomas E.M., Hillier W.D. (1999) Recent Canadian kimberlite discoveries. In J. J. Gurney et al., Eds., Proceedings of the VIIth International Kimberlite Conference, Vol. 1, Red Roof Design, Cape Town, pp. 81-89.

Carlson S.M., Hillier W.D., Hood C.T., Pryde R.P., Skelton D.N. (1999) The Buffalo Hills kimberlites: A newly-discovered diamondiferous kimberlite province in north-central Alberta, Canada. In J. J. Gurney et al., Eds., Proceedings of the VIIth International Kimberlite Conference, Vol. 1, Red Roof Design, Cape Town, pp. 109-116.

Davidson C.F. (1957) The diamond fields of Yakutia. Mining Magazine, Vol. 97, No. 6, pp. 329-338.

De Beers Consolidated Mines (2001) Circular to the holders of Linked Units, 10 April 2001, Appendix 2: Technical $\oplus$ Financial Report. Kimberley, South Africa, Sect. 2, p. 52.
Diamond Facts 2000/01 (2001) Northwest Territories Resources, Wildlife and Economic Development, Yellowknife.

Douglas G., MacGregor B. (1952) Diamond rush in Canada. Canadian Mining Journal, Vol. 73, No. 1, pp. 63-64.

Drucker R.B. (2000) Everyone's branding diamonds! Jewelers' Circular Keystone, Vol. 171, No. 7, pp. 132-135.

Dufresne M.B., Eccles D.R., McKinstry B., Schmitt D.R., Fenton M.M., Pawlowicz J.G., Edwards W.A.D. (1996) The Diamond Potential of Alberta. Alberta Geological Survey, Edmonton, Bulletin 63

Duval D., Green T., Louthean R. (1996) New Frontiers in Diamonds: The Mining Revolution. Rosendale Press, London.

The Ekati Diamond Mine (1998). Ekati Diamond Mine, Lac de Gras, N.W.T., Canada.

Ekati to 'brand' its diamonds (2001) Jewelers' Circular Keystone, Vol. 172, No. 7, pp. 54-56.

Even-Zohar C. (1999) The impact of new diamond marketing strategies on the diamond pipeline. Mazal U'Bracha Diamonds, Vol. 15, No. 115, pp. 35-46.

Even-Zohar C. (2001) Canada's diamond cutting industry. Mazal U'Bracha Diamonds, Vol. 16, No. 138, pp. 46-49.

Even-Zohar C. (2002) Diamond margins under pressure. Mining Journal, London, Vol. 338, No. 8689, pp. 437-438.

Farrington O.C. (1908) Correlation of distribution of copper and diamonds in the glacial drift of the Great Lakes region (abstract). Science, Vol. 27 (new series), No. 697, p. 729.

Field D.S.M. (1949) The question of diamonds in Canada. Journal of Gemmology, Vol. 2, No. 3, pp. 103-110.

Field D.S.M. (1950) Diamond pipes in Canada. Canadian Mining Journal, Vol. 71, No. 7, pp. 54-57.

Fipke C.E., Gurney J.J., Moore R.O. (1995a) Diamond Exploration Techniques Emphasising Indicator Mineral Geochemistry and Canadian Examples. Geological Survey of Canada, Ottawa, Bulletin 423.

Fipke C.E., Dummett H.T., Moore R.O., Carlson J.A., Ashley R.M., Gurney J.J., Kirkley M.B. (1995b) History of the discovery of diamondiferous kimberlites in the Northwest Territories, Canada. In N.V. Sobolev, Chairman, Extended Abstracts, Sixth International Kimberlite Conference, Novosibirsk, 1995, United Institute of Geology, Geophysics and Mineralogy, Siberian Branch of Russian Academy of Sciences, Novosibirsk, pp. 158-160.

Folinsbee R.E. (1955) Archean monazite in beach concentrates, Yellowknife Geologic Province, Northwest Territories, Canada. Transactions of the Royal Society of Canada, 3rd series, Section IV, Vol. 49, pp. 7-24

Frolick V. (1999) Fire into Ice: Charles Fipke and the Great Diamond Hunt. Raincoast Books, Vancouver.

Gehrisch W., Jenkins C., Leppin M. (1979) Report on Exploration Works with 14 DDH logs, Uranerz Mining and Exloration Ltd. Ministère des Ressources naturelles, Quebec, GM 34787 (Assessment Report). (Cited in Moorhead et al., 2000.)

Gent M.R. (1992a) Diamond exploration in Saskatchewan. Canadian Institute of Mining and Metallurgy Bulletin, Vol. 85, No. 956, pp. 64-71.

Gent M.R. (1992b) Diamonds and Precious Gems of the Phanerozoic Basin, Saskatchewan: Preliminary Investigations. Saskatchewan Geological Survey, Open File Report 92-2, Saskatchewan Energy and Mines, Regina.

Godwin C.I., Price B.J. (1986) Geology of the Mountain diatreme kimberlite, north-central Mackenzie Mountains, District of Mackenzie, Northwest Territories. In J.A. Morin, Ed., Mineral Deposits of Northern Cordillera, Special Volume 37, Canadian Institute of Mining and Metallurgy, Montreal, pp. $298-310$.

Gonzales T., Lockhart G., Carlson J.A. (2000) Exploration and discovery of kimberlites-EKATI ${ }^{\mathrm{TM}}$ Diamonds Project. GeoCanada 2000. The Millenium Geoscience Summit. 
Calgary, Alberta, May 29-June 2 (Conference CD-ROM, Abstract No. 1239, p. 2).

Graham I., Burgess J.L., Bryan D., Ravenscroft P.J., Thomas E., Doyle B.J., Hopkins R., Armstrong K.A. (1999) Exploration history and geology of the Diavik kimberlites, Lac de Gras, Northwest Territories, Canada. In J.J. Gurney et al., Eds., Proceedings of the VIIth International Kimberlite Conference, Vol. 1, Red Roof Design, Cape Town, pp. 262-279.

Gunn C.B. (1968) Relevance of the Great Lakes discoveries to Canadian diamond prospecting. Canadian Mining Journal, Vol. 89, No. 7, pp. 39-42.

Gurney J.J., Switzer G.S. (1973) The discovery of garnets closely related to diamonds in the Finsch pipe, South Africa. Contributions to Mineralogy and Petrology, Vol. 39, pp. 103-116.

Hall D.C., Helmstaedt H., Schulze D.J. (1989) The Cross diatreme, British Columbia, Canada: A kimberlite in a young orogenic belt. In J. Ross, Ed., Kimberlites and Related Rocks, Vol. 1, Proceedings of the Fourth International Kimberlite Conference, Perth, 1986, Geological Society of Australia Special Publication No. 14, Blackwell Scientific Publications, Oxford, pp. 97-108.

Harvie R. (1910) On the origin and relations of the Paleozoic breccia of the vicinity of Montreal. Transactions of the Royal Society of Canada, 3rd series, Vol. 3, pp. 249-299.

Hausel W.D. (1995) Diamonds, kimberlites, lamproites and related rocks in the United States. Exploration and Mining Geology, Vol. 4, No. 3, pp. 243-270.

Hobbs W.H. (1899) The diamond field of the Great Lakes. Journal of Geology, Vol. 7, No. 4, pp. 375-388.

Hovdebo M.R. (1957) Structure of the Brule-Crossing Creek area, British Columbia. Master of Science thesis, University of Saskatchewan (cited in Hall et al., 1989).

Ijewliw O.J., Pell J. (1996) Diatreme breccias in the Cordillera. In A.N. LeCheminant, D.G. Richardson, R.N.W. DiLabio, and K.A. Richardson, Eds., Searching for Diamonds in Canada. Geological Survey of Canada, Ottawa, Open File 3228, pp. 91-95.

Janse A.J.A. (1993) The aims and economic parameters of diamond exploration. In P. Sheahan and A. Chater, Eds., Diamonds: Exploration, Sampling and Evaluation. Proceedings of a Short Course on Diamond Exploration, Toronto, 1993, Prospectors and Developers Association of Canada, Toronto, pp. 173-184.

Janse A.J.A. (1995a) A history of diamond sources in Africa: Part I. Gems « Gemology, Vol. 31, No. 4, pp. 228-255.

Janse A.J.A. (1995b) Discovery of a new type of highly diamondiferous kimberlitic rock in the James Bay Lowlands, northern Ontario, Canada. In N.V. Sobolev, Chairman, Extended Abstracts, Sixth International Kimberlite Conference, Novosibirsk, 1995, United Institute of Geology, Geophysics and Mineralogy, Siberian Branch of Russian Academy of Sciences, Novosibirsk, pp. 260-262.

Janse A.J.A. (1996) A history of diamond sources in Africa: Part II. Gems et Gemology, Vol. 32, No. 1, pp. 2-30.

Janse A.J.A., Downie I.F., Reed L.E., Sinclair I.G.L. (1989) Alkaline intrusions in the Hudson Bay Lowlands, Canada: Exploration methods, petrology, and geochemistry. In J. Ross, Ed., Kimberlites and Related Rocks, Vol. 2, Proceedings of the Fourth International Kimberlite Conference, Perth, 1986, Geological Society of Australia Special Publication No. 14, Blackwell Scientific Publications, Oxford, pp. 1192-1203.

Janse B. [A.J.A.] (2001) Exploration overview. Mining Journal, London, Vol. 337, No. 8647, pp. 116-121.

Janse B. [A.J.A.] (2002) Canadian diamond developments. Mining Journal, London, Vol. 338, No. 8689, pp. 434, 436.

Jellicoe B.C., Robertson P., Williamson P., Murphy J. (1998) Summary of exploration activities and results from the Fort à la Corne diamond project, Saskatchewan. Summary of
Investigations 1998, Saskatchewan Geological Survey, Saskatchewan Energy and Mines, Miscellaneous Report 98-4, pp. 144-157.

Johnson M.J., Koivula J.I., Eds. (1998) Gem News: Diamond production starts at Canada's Ekati mine. Gems ↔ Gemology, Vol. 34, No. 4, pp. 290-292.

Kjarsgaard B.A. (1996) Somerset Island kimberlite field, District of Franklin, N.W.T. In A.N. LeCheminant, D.G. Richardson, R.N.W. DiLabio, and K.A. Richardson, Eds., Searching for Diamonds in Canada. Geological Survey of Canada, Ottawa, Open File 3228, pp. 61-66.

Kjarsgaard B.A. (1997) Diamonds in Alberta: Studies of potential host rocks of deep-seated origin and applications of indicator mineral exploration techniques. In R.W. Macqueen, Ed., Exploring for Minerals in Alberta: Geological Survey of Canada Geoscience Contributions, Canada-Alberta Agreement on Mineral Development (1992-1995). Geological Survey of Canada, Ottawa, Bulletin 500, pp. 185-207.

Kjarsgaard B.A., Wilkinson L., Armstrong J.A. (2002) Geology, Lac de Gras Kimberlite Field, Central Slave Province, Northwest Territories-Nunavut. Geological Survey of Canada, Ottawa, Open File 3238.

Kong J.M., Boucher D.R., Scott Smith B.H. (1999) Exploration and geology of the Attawapiskat kimberlites, James Bay Lowland, northern Ontario, Canada. In J.J. Gurney et al., Eds., Proceedings of the VIIth International Kimberlite Conference, Vol. 1, Red Roof Design, Cape Town, pp. 452-467.

Krajick K. (2001) Barren Lands: An Epic Search for Diamonds in the North American Arctic. W. H. Freeman, San Francisco.

Kunz G.F. (1906) Precious stones. In Mineral Resources of the United States, Calendar Year 1905, United States Geological Survey, pp. 1323-1358.

Kunz G.F. (1913) Precious stones. In C. Of, Ed., The Mineral Industry: Its Statistics, Technology and Trade During 1912, Vol. 21, McGraw-Hill Book Co., New York, pp. 707-736.

Kunz G.F. (1931) Diamonds in North America (abstract). Geological Society of America Bulletin, Vol. 42, No.1, pp. 221-222.

Laurs B.M. (2001) Gem News International: Report from the 2nd World Diamond Conference, Vancouver. Gems e) Gemology, Vol. 37, No. 3, pp. 222-225.

Leckie D.A., Kjarsgaard B., Pierce J.W., Grist A.M., Collins M., Sweet A., Stasiuk L., Tomica M.A., Eccles R., Dufresne M., Fenton M.M., Pawlowicz J.G., Balzer S.A., McIntyre D.J. McNeil D.H. (1997) Geology of a Late Cretaceous Possible Kimberlite at Mountain Lake, Alberta-Chemistry, Petrology, Indicator Minerals, Aeromagnetic Signature, Age, Stratigraphic Position and Setting. Geological Survey of Canada, Ottawa, Open File 3441.

Lee H.A. (1965) 1. Investigation of Eskers for Mineral Exploration. 2. Buried Valleys near Kirkland Lake, Ontario. Geological Survey of Canada, Ottawa, Paper 65-14.

Lee H.A., Lawrence D.E. (1968) A New Occurrence of Kimberlite in Gauthier Township, Ontario. Geological Survey of Canada, Ottawa, Paper 68-22.

Lehnert-Theil K., Loewer R., Orr R.G., Robertshaw P. (1992) Diamond-bearing kimberlites in Saskatchewan, Canada: The Fort à la Corne case history. Exploration and Mining Geology, Vol. 1, No. 4, pp. 391-403.

Levinson A.A., Gurney J.J., Kirkley M. B. (1992) Diamond sources and production: Past, present, and future. Gems «) Gemology, Vol. 28, No. 4, pp. 234-254.

Markovic T. (1999) Additions to kimberlite resource-Sable, Pigeon and Beartooth pipes. BHP Diamonds Newsletter, No. 2, p. 7.

McClenaghan M.B, Kjarsgaard B.A. (2001) Indicator mineral and geochemical methods for diamond exploration in glaciated ter- 
rain in Canada. In M.B. McClenaghan, P.T. Bobrowsky, G.E.M. Hall, and S.J. Cook, Eds., Drift Exploration in Glaciated Terrain. Geological Society (London), Special Publication No. 185 , pp. 83-123.

McClenaghan M.B., Bobrowsky P.T., Hall G.E.M., Cook S.J. (2001) Drift Exploration in Glaciated Terrain. Geological Society (London), Special Publication No. 185.

McKinlay F.T., Scott Smith B.H., de Gasparis S., Kong J. (1998) Geology of the recently discovered Hardy Lake kimberites, NWT. Seventh International Kimberlite Conference, Extended Abstracts, Cape Town, pp. 564-566.

Meen V.B. (1950) Are there diamonds in the Precambrian? Northern Miner, Annual Number (November 30), p. 99.

Mitchell R.H. (1983) The Ile Bizard intrusion, Montreal, Quebec-kimberlite or lamprophyre?: Discussion. Canadian Journal of Earth Sciences, Vol. 20, pp. 1493-1496.

Mitchell R.H., Fritz, P. (1973) Kimberlite from Somerset Island, District of Franklin, N.W.T. Canadian Journal of Earth Sciences, Vol. 10, pp. 384-393.

Moorhead J., Perreault S., Berclaz A., Sharma K.N.M., Beaumier M., Cadieux A-M. (2000) Kimberlites and Diamonds in Northern Quebec. Géologie Québec, PRO 99-09, Ministère de Ressources naturelles, Secteur des Mines, Gouvernement du Québec.

Morton R.D., Stewart J.P., Bale W.C., Day R.C. (1993) A review of diamond occurrences and potentials in Alberta. In K.P.E. Dunne and B. Grant, Eds., Mid-Continent Diamonds, GACMAC Symposium Volume, Edmonton, Alberta, May 17-18, 1993, Mineral Deposits Division, Geological Association of Canada, pp. 101-104.

Natural Resources Canada (2000) Overview of Trends in Canadian Mineral Exploration 1999. Minister of Public Works and Government Services Canada, Ottawa (www.nrcan.gc.ca/mms/efab/invest/exploration).

Natural Resources Canada (2002) Overview of Trends in Canadian Mineral Exploration 2001. Minister of Public Works and Government Services Canada, Ottawa (www.nrcan.gc.ca/mms/efab/invest/exploration).

Oppenheimer N. (2002) Mostly a matter of marketing. Mazal U'Bracha Diamonds, Vol. 17, No. 146, pp. 28-32, 34-36.

Paget D. (1999) Canadian diamond production: A government perspective. Gems «) Gemology, Vol. 35, No. 3, pp. 40-42.

Pell J. (1987) Alkalic ultrabasic diatremes in British Columbia: Petrology, geochronology and tectonic significance (82G, J. N.; 83C; 94B). In Geological Fieldwork 1986, British Columbia Ministry of Energy, Mines and Petroleum Resources, Victoria, Paper 1987-1, pp. 259-272.

Pell J. (1994) Kimberlites and diamond exploration in the Slave Structural Province, NWT. Canadian Gemmologist, Vol. 15, No. 3, pp. 67-73.

Raeside R.P., Helmstaedt H. (1982) The Ile Bizard intrusion, Montreal, Quebec-kimberlite or lamprophyre? Canadian Journal of Earth Sciences, Vol. 19, pp. 1996-2005.

Reed L.E., Sinclair I.G.L. (1991) The search for kimberlite in the James Bay Lowlands of Ontario. Canadian Institute of Mining and Metallurgy Bulletin, Vol. 84, No. 947, pp. 132-139.

Robertson R. (2002a) BHP options Alberta diamond project. Northern Miner, Vol. 88, No. 4, pp. 1, 12, 13.

Robertson R. (2002b) Slave Craton district still hot as market awaits results. Northern Miner, Vol. 88, No. 17, pp. B1, B4, B10-B11.

Robertson R. (2002c) Diamond potential near Wawa lures big guns. Northern Miner, Vol. 88, No. 10, pp. 1, 16.

Robertson R. (2002d) Otish Mountains augurs well for diamond search in '02. Northern Miner, Vol. 88, No. 3, pp. B1-B3, B6-B8.

Robertson R. (2002e) Diamonds North targets Victoria Island. Northern Miner, Vol. 88, No. 20, pp. 1, 2, 16.
Robertson R. (2002f) De Beers confirms commitment to Canada. Northern Miner, Vol. 88, No. 26, pp. 1, 6

Robertson R. (2002g) Fort à la Corne play takes shape. Northern Miner, Vol. 88, No. 17, pp. B1, B6-B8, B11.

Robinson A. (2002) Tiffany to build diamond plant. The Globe and Mail, October 2, pp. B1, B7.

Rombouts L. (1999) Extreme value analysis of diamond sizes and values. In J. J. Gurney et al., Eds., Proceedings of the VIIth International Kimberlite Conference, Vol. 2, Red Roof Design, Cape Town, pp. 721-727.

Rombouts L. (2000) The diamond-mining scene. Mining Journal, London, Vol. 334, No. 8587, pp. 464-466.

Rombouts L. (2001) Diamonds-industry review. Mining Journal, London, Vol. 337, No. 8647, pp. 113, 115-116.

Rombouts L. (2002) World natural diamond production 2001. Mining Journal, London, Vol. 339, No. 8699, p. 131.

Sage R.P. (1993) Project Unit 93-12. Kimberlites in Ontario. In C.L. Baker, B.O. Dressler, H.A.F. de Souza, K.G. Fenwick, J.W. Newsome, and L. Owsiacki, Eds., Summary of Field Work and Other Activities 1993, Ontario Geological Survey, Toronto, Miscellaneous Paper 162, pp. 111-113.

Sage R.P. (1996) Kimberlites of the Lake Timiskaming Structural Zone. Ontario Geological Survey, Open File Report 5937.

Satterly J. (1949) Geology of Michaud Township. Ontario Department of Mines, 57th Annual Report, Vol. LVII, Part IV, 1948.

Scott Smith B.H., Letendre J.P., Robison H.R. (1996) Geology of the Sturgeon Lake 01 kimberlite block, Saskatchewan. Exploration and Mining Geology, Vol. 5, No. 3, pp. 251-261.

Scriven S. (1997) Brand name diamonds: The strategic future of diamond marketing. Mazal U'Bracha, Vol. 14, No. 97, pp. 43-46. 48.

Sevdermish M., Miciak A.R., Levinson A.A. (1998) The diamond pipeline into the third millennium: A multi-channel system from the mine to the consumer. Geoscience Canada, Vol. 25, No. 2, pp. 71-83.

Sielaff W., Moderator (1999) Branding war room. Gems ↔) Gemology, Vol. 35, No. 3, pp. 130-131.

Smillie I. (2002) Fire in the ice. Mazal U'Bracha Diamonds, Vol. 17 , No. 143 , pp. $30-57$.

Smith C.H. (1960) Diamonds in the Great Lakes area-A geological enigma. Canadian Mining Journal, Vol. 81, No. 7, pp. 51-52.

Strnad J. (1991) The discovery of diamonds in Siberia and other northern regions: Explorational, historical, and personal notes. Earth Sciences History, Vol. 10, No. 2, pp. 227-246.

Thomas R.D., Gleeson C.F. (2000) Use of till geochemistry and mineralogy to outline areas underlain by diamondiferous spessartine dikes near Wawa, Ontario. Exploration and Mining Geology, Vol. 9, Nos. 3-4, pp. 215-231.

Turner R., McConnell J. (2001) The Snap Lake diamond deposit, Northwest Territories. Technical Program «) Core Shack Abstracts, Paper W-4, Prospectors and Developers Association of Canada, Annual Meeting, March 11-14, Toronto.

Waytiuk J. (2001) The fifth C. Canadian Diamonds, Fall 2001, pp. $28-31$

Williams W.S. and Carlson J.A. (2001) EKATT ${ }^{\mathrm{TM}}$ Diamond MineAn update. Industrial Minerals in Canada, Program and Extended Abstracts for the 37th Forum on Geology of Industrial Minerals, Victoria, British Columbia, May 22-25, p. 113.

Wolfe W.J., Lee H.A., Hickes W.D. (1975) Heavy Mineral Indicators in Alluvial and Esker Gravels of the Moose River Basin, James Bay Lowlands, District of Cochrane. Ontario Division of Mines, Toronto, Geoscience Report 126.

Wood B. (2002) De Beers Victor project. Technical Program e) Core Shack Abstracts, Paper M-15. Prospectors and Developers Association of Canada, Annual Meeting, March 10-13, Toronto. 